\title{
Transcriptomic response to methyl jasmonate treatment of Scots pine (Pinus sylvestris) seedlings
}

\author{
Krista Kānberga-Siliņa' ', Elza Rauda', Vilnis Šķipars' , Adam Vivian-Smith², Igor Yakovlev², \\ Baiba Krivmane', Ilze Šñepste', Dainis Rungóis ${ }^{1 *}$ \\ ${ }^{1}$ Genetic Resource Centre, Latvian State Forest Research Institute "Silava”, Rigas 111, Salaspils LV-2169, Latvia \\ ${ }^{2}$ Norwegian Institute of Bioeconomy Research, Section Forest Genetics and Biodiversity, Høgskoleveien 8, 1433 Ås, Norway \\ *Corresponding author, E-mail: dainis.rungis@silava.lv
}

\begin{abstract}
Scots pine (Pinus sylvestris L.) has high ecological and economic importance in Latvia. Induced resistance can protect trees from pathogen attack, and has potential for sustainable pest management. The effect of methyl jasmonate (MeJA) on the gene expression profile of Scots pine was determined in order to assess its potential to induce resistance. Two year old Scots pine ramets were treated with $10 \mathrm{mM}$ MeJA and needle samples were collected two weeks after treatment. RNA was isolated from samples and transcription profiling was performed using the Ion Torrent PGM platform, and RT-PCR was used to confirm expression profiles for selected genes. Gene expression profiles results were summarized by a gene network analysis using gene functionality annotations. Results revealed that MeJA treatment diverts metabolic functions from growth and development to defensive pathways. Analysis of the transcriptome indicated that the MeJA treated Scots pine clone had an altered gene expression profile two weeks after the treatment, suggesting that the induction of defence mechanisms was still active at this time. The organism is in an induced state at least two weeks after the treatment, which confirms the potential of the MeJA use to induce resistance responses in Scots pine trees.
\end{abstract}

Key words: gene profiles. induced resistance, methyl jasmonate, next generation sequencing, Scots pine.

Abbreviations: DEG, differentially expressed gene; MeJA, methyl jasmonate; RT-PCR, real time polymerase chain reaction.

\section{Introduction}

Scots pine (Pinus sylvestris L.) has the largest natural distribution of any pine species (Richarson, Rundel 1998). In Europe, Scots pine covers at least $20 \%$ of the forested area (Masón, Alía 2000; Brus et al. 2011). While having a high economical value, conifers are susceptible to various pathogens, like root and butt rot caused by Heterobasidion annosum (Asiegbu et al. 2005), and in Latvia, almost half of the forested areas are affected by a variety of pathogens and pests every year (http://www.csb.gov.lv/statistikas-temas/ mezsaimnieciba-publikacijas-43247.html). One possible approach to protect plants from pathogen attack is to prime and induce innate resistance responses, which enable plants to respond more rapidly to infections by limiting pathogen development (Hammerschmidt 1999).

It is important for a tree to protect itself from pathogens and diseases, but to also balance resource allocation between defence and growth processes, such as wood formation (Smith 2015). Phenylpropanoids and terpenes are defence compounds used by plants (Wink 1988), but the phenylpropanoid biosynthesis pathway also produces lignin precursors and other compounds related to wood formation (Whetten, Sederoff 1995; Hatfield, Vermerris 2001). In vitro studies have revealed a strong relationship between the carbohydrate supply and the formation of phenolic compounds in apple tree shoot cultures, indicating competition for carbohydrates between growth-related and defence-related metabolic processes (Lux-Endrich et al. 2000).

Chitinases are enzymes that hydrolyse chitin, which is a homopolymer of $\mathrm{N}$-acetylglucosamine. Chitin is a structural component in fungal and some algae cell walls, as well as in arthropod shells and cuticles (Sahai, Manocha 1993). In plants, chitinase genes are represented by large gene families. It is possible that each chitinase plays a different role in the protection of the plant against different pathogens (Schlumbaum et al. 1986), though some may also exhibit activity towards structural compounds that have similarity to chitin, which in turn, have important roles in plant development (Passarinho, De Vries 2002). Several classes of chitinase genes are distinguished based on their amino acid sequences. In plants, chitinases from classes I, II and IV are most abundant (Shinshi et al. 1990; Iseli et al. 1993; Cohen-Kupiec et al. 1998). One chitinase gene from each of these three classes was selected to validate their expression using real time polymerase chain reaction (RTPCR). It has been previously reported that the expression of chitinase genes increases after methyl jasmonate (MeJA) treatment, and that different chitinase genes, even within 
same class, can exhibit differential expression patterns (Su et al. 2015).

MeJA is a compound that participates in plant defense response mediation, including inducing expression of proteinase inhibitor genes and wound-response genes (Farmer, Ryan 1990; Creelman et al. 1997). Jasmonate has been shown to play a significant role in plant pathogen resistance (Vijayan et al. 1998). MeJA significantly increases monoterpene concentration in the xylem of Pinus armandi saplings (Pham et al. 2014). Many conifers possess defence responses that are induced in response to insect attack, MeJA treatment, mechanical wounding or fungal inoculation (Creelman et al. 1997; Miller et al. 2005; Moreira et al. 2009). These induced defences include the activation of existing resin ducts and the developmental formation of traumatic resin duct systems in the bark and xylem (Hudgins et al. 2003). It has been reported that application of $100 \mathrm{mmol} \mathrm{L}^{-1} \mathrm{MeJA}$ to intact bark of Norway spruce induces anatomical defense reactions within 30 days (Franceschi et al. 2002). In field experiments, application of MeJA to individuals prior to planting considerably reduced weevil-caused mortality in P. sylvestris (Zas et al. 2014). In Norway spruce, MeJA treatment resulted in up-regulation of the PaPX3 and PaChi4 genes, and the genes involved in lignin biosynthesis PaPAL1, PaPAL2, PaC4H3/5 and $P a H C T 1$. Likewise, the ethylene biosynthesis related genes $\mathrm{PaACO}$ and $\mathrm{PaACS}$ were also induced by MeJA treatment (Yaqoob et al. 2012).

High-throughput sequencing and bioinformatics tools have been used to investigate the influence of various factors on gene expression in plants (Hoth et al. 2002; Liu et al. 2014). Next generation sequencing allows for gene expression profiling even in non-model organisms, where genome sequences are not available (Morozova, Marra 2008). A high quality genome sequence is not available for $P$. sylvestris; however, partial transcriptomes have been published (Sun et al. 2011, Wachowiak et al. 2015). Microarrays have been successfully used to profile gene expression in Pinus radiata saplings exposed to ethephon, but using RNA-Seq could provide a better understanding of gene expression, since the later types of methods do not rely on sequences to designed complementary oligonucleotide probes (Dubouzet et al. 2014).

This study investigated differential gene expression profiles in one P. sylvestris clone two weeks after MeJA treatment using high throughput RNA sequencing methods. Differentially expressed genes (DEGs) were annotated, and gene expression networks were generated. RT-PCR was used to validate the expression of three chitinase genes.

\section{Materials and methods}

\section{Plant material and treatment}

Six two-year-old P. sylvestris ramets of clone Sm 9-III-2 were grown in a climate chamber for two months prior to the experiment. Three ramets were treated with $5 \mathrm{~mL} 10 \mathrm{mM}$ MeJA in $0.1 \%$ Tween 80 . Three other ramets were sprayed with $5 \mathrm{~mL} 0.1 \%$ Tween 80 as a control. After treatment, all ramets were placed in clear plastic bags for two days to avoid cross reaction with volatile compounds. Growth conditions in the climate chamber were $8 \mathrm{~h}$ darkness and $16 \mathrm{~h}$ light at 17 to $22^{\circ} \mathrm{C}$ temperature. Two weeks after the treatment needles were collected and stored at $-80^{\circ} \mathrm{C}$.

\section{RNA extraction}

The CTAB buffer-based method (Yang et al. 2008) was used for total RNA extraction with modifications as described by Rubio-Piña and Zapata-Pérez (2011). RNA quantity was assessed fluorometrically using a Qubit fluorometer and Quant-iT reagents (Invitrogen) following the manufacturer's instructions. RNA extracts were treated using DNase I (Thermo Fisher) and purified using a standard phenol/chloroform extraction.

\section{Next generation sequencing}

Next generation sequencing was done in collaboration with the Norwegian Institute of Bioeconomy Research (NIBIO). The quality, quantity and structural integrity of total RNA was assessed using an Agilent Technologies 2100 Bioanalyzer with Agilent RNA 6000 Nano and Pico Kits according to manufacturer's instructions.

RNA samples were enriched for polyadenylated mRNAs from the total RNA samples using the Dynabeads mRNA DIRECT ${ }^{\mathrm{Tm}}$ Micro Kit (Life Technologies). The quantity of total extracted from one of the treated samples (Sm8) was not sufficient for library construction; therefore, five transcriptome libraries were produced using the Ion Total RNA-Seq Kit v2 (Life Technologies) according to the manufacturer's instructions. RNA quantity and fragment size was assessed by the Qubit RNA Assay Kit on a Qubit Fluorometer and the Agilent RNA 6000 Pico Kit using an Agilent 2100 Bioanalyzer (Thermo Fisher Scientific) following the manufacturers' protocols. Sequencing was carried out using the Ion $\mathrm{PGM}^{\mathrm{m}}$ Sequencing 200Kit v2 (catalogue No. 4482006) on Ion $318^{\mathrm{mm}} \mathrm{v} 2$ Chips according to the manufacturer's protocol.

\section{Real time $P C R$}

For confirmation of expression profiles, three chitinase genes were selected, each representing a different chitinase class: I, II and VII. Sequences for primer design were obtained from the expressed sequence transcript consensus sequences. Several primer pairs for each gene were designed using the Primer3 software (http://bioinfo.ut.ee/primer3/). The primers with the highest efficiency (at least 90\%) were used for further analysis (Table 1).

DNA was synthesiz'ed using TaqMan Reverse Transcription reagents (Applied biosystems) according to the manufacturer's protocol. Gene expression was determined using the comparative $\Delta \Delta \mathrm{Ct}$ RT-PCR method 
Table 1. Primer sequences and annealing temperatures

\begin{tabular}{|c|c|c|}
\hline Primer & Sequence $\left(5^{\prime}-3^{\prime}\right)$ & Annealing temperature \\
\hline Chit1.3F & CGGCAGCTAATAGTTTCCCA & $57^{\circ} \mathrm{C}$ \\
\hline Chit1.3R & GAAGTTTGGCCGAAGAAAGC & \\
\hline Chit2.1F & TTTAAGACGGCGGTGTGGTT & $60{ }^{\circ} \mathrm{C}$ \\
\hline Chit2.1R & ACCCCGCCGTTAATGATGTT & \\
\hline Chit7.2F & ACTGCGATTCCACCTACACG & $60^{\circ} \mathrm{C}$ \\
\hline Chit7.2R & AGCCCAGGTAATTTCCAGCG & \\
\hline GapdhF & ACGGTTTTGGTCGAATTGGA & $60^{\circ} \mathrm{C}$ \\
\hline GapdhR & CCCCACGAGCTCGATATCAT & \\
\hline Tub5F & CCACATTGGACAGGCCGGTATCC & $60^{\circ} \mathrm{C}$ \\
\hline Tub5R & AATGCCGTGCTCGAGGCAGTA & \\
\hline Act5F & TCATGGTTGGCATGGGACAG & $60^{\circ} \mathrm{C}$ \\
\hline Act5R & CTCCATGTCATCCCAGTTGC & \\
\hline
\end{tabular}

with three endogenous control genes as references for normalization: GAPDH (glyceraldehyde-3-phosphate dehydrogenase; Škipars et al. 2011); TUB (tubulin) and ACT (actin; Kānberga-Siliņa, unpublished). Primers and annealing temperatures are shown in Table 1. Experiments were run on a StepOnePlus Real-Time PCR System using 5x HOT FIRE Pol EvaGreen qPCR SuperMix reagents (Solis BioDyne) according to the manufacturer's protocol.

Real time PCR data was analyzed using StepOne software v2.2. Relative quantity of all candidate genes was calculated using all three endogenous control gene $\Delta \Delta \mathrm{C}$ T values.

\section{Data analysis}

DNase Fastq format sequence data were analyzed using the CLC Genomics Workbench 7.5.1. software (QIAGEN, Aarhus, Denmark). Due to the absence of a high quality $P$. sylvestris genome sequence, expressed sequences were utilized using the reference sequences (Wachowiak et al. 2015). Fastq files were imported using the SAM/ BAM procedure and the low quality reads ( $Q$ value < 20) were excluded from analysis. Transcriptome libraries for each sample were separately mapped to the reference transcriptome using the RNA-Seq tool with the following parameters: gap cost 2 , indel cost 3 and length and a similarity fraction of 0.8. Results were then exported for further data normalization and comparison in the R environment using DESeq library (Anders and Huber 2010). All sample data were grouped as "treated" and "control". Using the "fdr" method, $\log \mathrm{FC}$ values were obtained, and only reads with $\log \mathrm{FC}$ values $>|2|$ were used for further analysis.

To annotate transcriptome sequences we used BLAST for comparing the differentially expressed sequences with the NCBI database (http://www.ncbi.nlm.nih.gov/). Each sequence was annotated separately at $80 \%$ identity threshold.

Gene expression networks were generated using the Cytoscape 3.2.1 program with the GeneMANIA plug-in (Montojo et al. 2014). The program uses several databases containing information on gene interactions to create a gene network that visually represents the relationship between genes. The NCBI BLASTx was used to identify Arabidopsis thaliana protein homologues for the DEGs defined in this study. Two separate networks were created depicting the interactions of the up and down regulated gene groups. The GeneMANIA plugin also provides annotations for gene functionality, which were used to classify the DEGs into functional groups.

\section{Results}

\section{Sequencing of gene expression libraries}

Five gene expression libraries were sequenced using the Ion Torrent PGM. An average of $76.38 \%$ of reads per library were successfully mapped onto the reference transcriptome (Table 2). Using RNA-Seq analysis for each read library we obtained expressed reference contigs, which were further analyzed using the FDR (False Discovery Rate) tool in R. A total of 284 sequences were found to be differentially expressed, while 206 were upregulated in MeJA treated samples and 78 sequences were more highly expressed in the control samples. DEGs were annotated with BLASTn (Appendix 1). Among the most highly expressed up regulated genes was a carbonic anhydrase (KEH16352.1), an acid phosphate (CAC84485.1), and a gene with similarity to an alpha terpineol/1,8-cineole synthase (AFU73861.1). Among the down regulated genes, three genes were highly expressed in the control libraries: an anthocyanidin reductase (AAU95082.1), a 50S ribosomal protein L3 (WP_014093814.1), and a Leucine-Rich Receptor-like protein (XP_007018364.1).

\section{Gene networks}

Protein homologues from A. thaliana were identified for all of the differentially expressed gene sequences, and gene networks were created for both upregulated and down regulated genes using GeneMANIA in Cytoscape. Both gene groups formed one network for each group 
Table 2. RNA-Seq mapping results. Sm3 and $\mathrm{Sm} 4$ are treated sample libraries, Sm5, Sm6 and Sm7 are control libraries

\begin{tabular}{|c|c|c|c|c|c|}
\hline Sample name & Sm3 & Sm4 & Sm5 & Sm6 & Sm7 \\
\hline Number of reads & 1975699 & 1496742 & 1807085 & 4543929 & 885484 \\
\hline Mapped fragments & 1619297 & 1161871 & 1352336 & 3770254 & 571301 \\
\hline Average read length,bp & 143 & 185 & 185 & 194 & 208 \\
\hline $\begin{array}{l}\text { Proportion of reads mapped } \\
\text { to reference sequence }\end{array}$ & $81.96 \%$ & $77.63 \%$ & $74.84 \%$ & $82.97 \%$ & $64.52 \%$ \\
\hline
\end{tabular}

without substructures. From the upregulated group, 12 genes (LSU3; AT1G15240/F9L1_19; ILR2; T2D23.3; LOB; AT4G23895; NDR1; AT1G59312; AT2G1400D; AT3G59210; ATPAO3; PIP3) were not included in the gene network, and likewise another 10 genes were not included from the down regulated group (DREB2C; AT4G31480; CRRSP18; PLP5; T22P22_10; FIB; F19C17.40; RPS12; PLL3; BRCC36A). The upregulated gene network was more centrally organized (Appendix 2), while the downregulated network contained an expanded and less concentrated network at specific nodes (Appendix 3).

According to gene ontology classification, the upregulated group was dominated by genes that respond to a range of stimuli and are involved in metabolic processes. Only a small fraction of these genes were directly categorized as involved in defence processes. The downregulated gene group was dominated by genes involved in metabolic, developmental processes and cell formation (Fig. 1).

\section{Chitinase gene expression}

Gene expression of representatives of three chitinase groups was also determined using RT-PCR: group I (Chit1), group II (Chit2) and group VII (Chit7). The group I chitinase showed a higher expression in treated samples ( $\mathrm{Sm} 3, \mathrm{Sm} 4$, Sm8) than in controls, but overall the expression levels were relatively low (Fig. 2). The overall relative expression of the group II chitinase gene was slightly higher and more equal between treated and control samples. Expression of the group VII chitinase gene was the lowest overall, but it was more highly expressed in the MeJA treated samples than in the controls. The highest gene expression level for all three genes was detected in the sample Sm3 (Fig. 2 ). The expression profiles of these three chitinase genes were similar to the relative expressions identified from the transcriptome profiling data. However, these genes were not included in the upregulated gene group as the relative expression values between treated and control libraries did not exceed the $\log \mathrm{FC}$ value $>|2|$ threshold.

\section{Discussion}

Efficient analysis of gene expression using high-throughput sequencing data requires a high quality reference sequence. Initially, a different Scots pine transcriptome reference sequence ERR015466 (Sun et al. 2011) was utilized for transcript mapping. This resulted in the identification of a large amount of repetitive and retrotransposon sequences in our data, which was not unexpected, as approximately $75 \%$ of the conifer genomes is composed of repetitive sequences and retrotransposons (Ahuja, Neale 2005). Analysis of the Pinus taeda genome sequence revealed that analysis parameters utilized for sequence assembly can influence the identification of repetitive sequences (Kovach et al. 2010), which might explain the large number of repetitive sequences identified using the initial reference sequences. Subsequent data analysis was performed with an alternative Scots pine transcriptome as a reference (Wachowiak et al. 2015), and this allowed us to obtain more informative results with a larger number of protein-coding genes being identified, since this study identified 19659 separate contigs representing a total of 40968 unigenes. This means that the reference sequences utilized for transcript
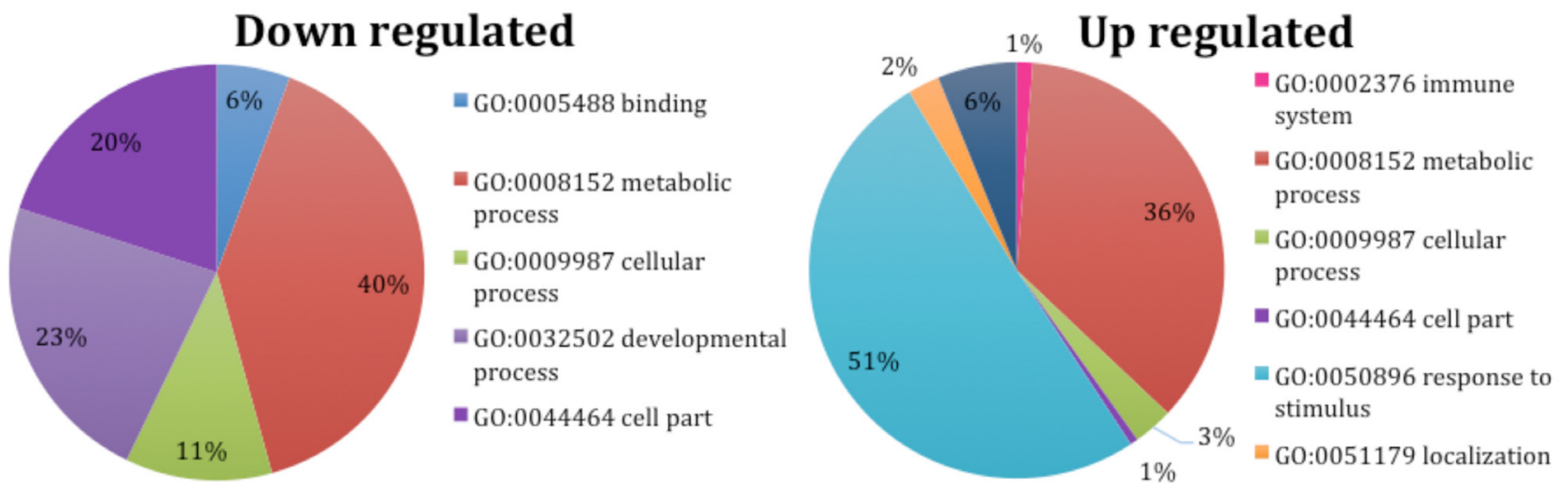

Fig. 1. Gene ontology annotation summary of central genes in up and down regulated gene networks. 


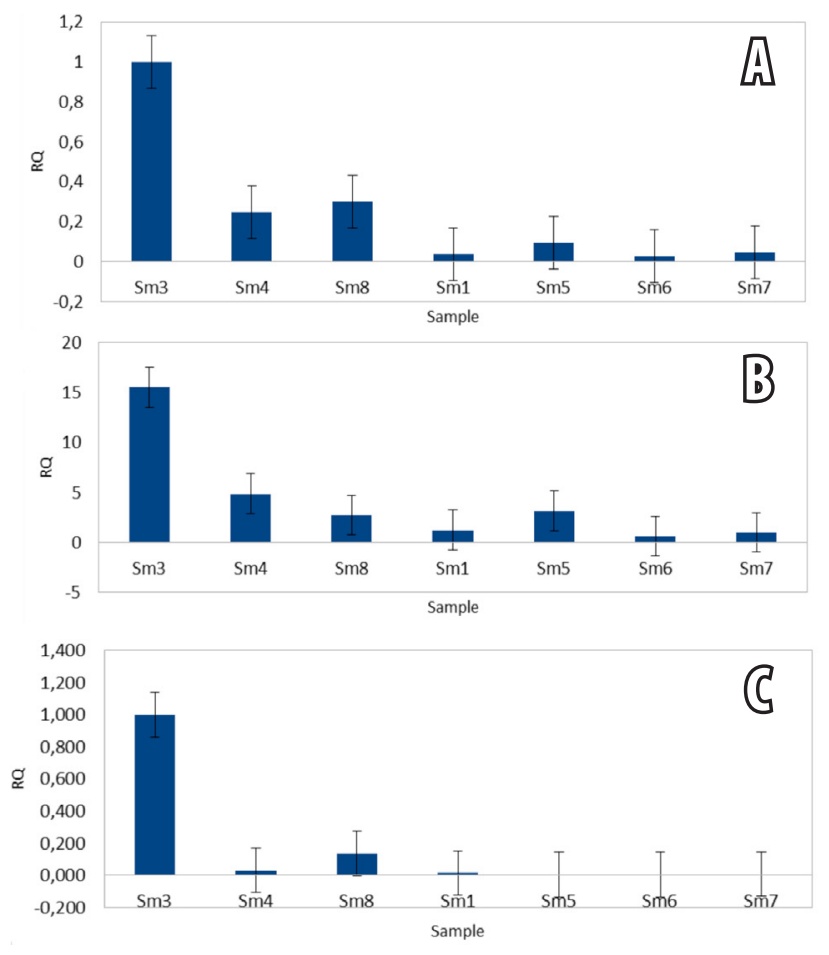

Fig. 2. Group I (A), II (B), VII (C) chitinase relative gene expression (RQ), where $\mathrm{Sm} 3, \mathrm{Sm} 4$, and $\mathrm{Sm} 8$ are treated samples and Sm1, Sm5, Sm6 and Sm7 are control samples.

mapping had a much deeper coverage than the first library (ERR015466), but even so, the later study may have not been sufficiently representative of the full genomic complement of transcribed genes. The lack of a completely annotated $P$. sylvestris genome, or exomic complement, combined with information on differential splicing, might have reduced the overall accuracy and discovery of differentially transcribed genes in this study.

Seven of the genes down regulated after MeJA treatment are photosystem related, indicating that treated samples have reduced allocation of resources to the photosystem and that biosynthetic pathways have been reorientated to different processes, which is a typical plant response to biotic attacks (Bilgin et al. 2010). Plants can maintain photosynthetic capacity despite the activation of the defence process signalling system; however, growth of the trees can be affected (Attaran et al. 2014). The induction of defence processes can result in slower growth and development, but the individuals would have increased resistance to pathogens, since metabolism, prior to the pathogen attack, would be orientated towards defence processes. Uninduced plants are not primed for the production of defence related metabolic processes, and this provides a direct advantage to the pathogen.

It has been reported that in sugarcane, the activity of Class VII chitinase gradually decreases over time after treatment with MeJA (Su et al. 2015), which could explain the relatively low expression of this gene compared to other two chitinase genes in our study. The relatively higher expression levels of the chitinase genes detected by RT-PCR in sample Sm3 were not found in the analysis of the RNASeq data. The expression of the chitinase genes was elevated in all of the MeJA treated libraries, but the difference in gene expression was below the threshold set for identification of differentially expressed genes $(\log \mathrm{FC}$ value $>|2|)$. The cause of the high levels of chitinase gene expression in sample $\mathrm{Sm} 3$ was not immediately obvious. One possibility is that this individual was additionally traumatized at the time of sampling or shortly before, but there was no visual or other evidence to support this. Another possibility is that this individual had some undiagnosed infection or variability, which could also lead to enhanced expression of chitinases (Schlumbaum et al. 1986; Fracetto et al. 2013). Treatment with salicylic acid, MeJA, and abscisic acid has shown that different chitinase genes, even within same class, are transcribed differentially over time (Su et al. 2015). The Chit1 gene is the most promising for induced resistance activity, as class I chitinases have the potential to directly inhibit fungal pathogens, because of their chitinolytic activity.

One of the genes with highest upregulated expression after MeJA treatment was the acidic phosphatase gene. This is a non-specific enzyme that is most likely to be needed in phosphorus hydrolysis and mobilization (Duff et al. 1994). Increased expression of this gene is also observed in senescing A. thaliana leaves, where it could participate in the mobilization of phosphate, which is released during nucleic acid degradation (Buchanan-Wollaston et al. 2005). In addition, three different purple acidic phosphatase genes were detected in the upregulated gene group. This enzyme catalyzes the hydrolysis of various phosphomonoesters and amide substrates, as well as the production of phosphorus in plants (Schenk et al. 2013). In P. pinaster it has been observed that higher availability of phosphorus reduces resin accumulation and increases its release in the needles (Blanch et al. 2012). At high concentrations, monoterpenes have pest repellent and moderate fungicidal properties (Everaerts et al. 2012). This means that MeJA could promote resin release, which has the potential to facilitate plant resistance to a variety of pests.

The upregulated gene network was highly centred, with no separate gene subgroups, indicating that the MeJA treatment triggers the activation of a related gene cascade and a unified response. The downregulated gene network suggests a more general gene expression response that is not focused on one function. In addition, a summary of GO annotations indicate that the expressed genes are more evenly distributed among various functions intended to provide basic functions of the organism. It should be noted that the results do not examine the genes that are similarly expressed in both groups $(<2$ times gene expression difference).

Our results show that in samples treated with MeJA, two 
weeks after treatment, the increased expression of signal transduction genes can be detected. This suggests that the organism is in an induced state, and that in the event of a pest attack, the plant may respond more rapidly to the infection process or other stress conditions. However, Scots pine as a species has high ecological plasticity and genetic variability even within a single population (Sevik et al. 2010; Salmela et al.2013), which influences the response of individuals to a variety of factors. As only one P. sylvestris clone was used in our experiment, these results need to be replicated or verified using a larger number of individuals from a different population. In addition, further time points would be required to determine the duration of the response to MeJA treatment.

A similar study in Picea sitchensis, which investigated gene expression in injured plants affected by insect feeding, showed that several thousand genes are activated in defense responses (Ralph et al. 2006). Expression of similar genes is also evident in our results and indicates that the MeJA treated Scots pine individual had an altered gene expression profile two weeks after the treatment, potentially increasing survival and resistance to pathogen attack.

\section{Acknowledgements}

This study was performed within the framework of the Latvian Council of Science project Investigation of molecular defense mechanisms in Scots pine (Pinus sylvestris L.) (No. 284/2012). We would like to thank Carl Gunnar Fossdal Norwegian Institute of Bioeconomy Research for assistance with the project.

\section{References}

Ahuja M.R., Neale D.B. 2005. Evolution of genome size in conifers. Silvae Genet. 54: 126-137.

Anders S., Huber W. 2010. Differential expression analysis for sequence count data. Genome Biol. 11: R106.

Asiegbu F.O., Adomas A., Stenlid J. 2005. Conifer root and butt rot caused by Heterobasidion annosum (Fr.) Bref. sl. Molec. Plant Pathol. 6: 395-409.

Attaran E., Major I.T., Cruz J.A., Rosa B.A., Koo A.J., Chen J., Kramer D.M., He S. Y., Howe G.A. 2014. Temporal dynamics of growth and photosynthesis suppression in response to jasmonate signalling. Plant Physiol. 165: 1302-1314.

Bilgin D.D., Zavala J.A., Zhu J.I.N., Clough S.J., Ort D.R., DeLucia E.H. 2010. Biotic stress globally downregulates photosynthesis genes. Plant Cell Environ. 33: 1597-1613.

Blanch J.S., Sampedro L., Llusià J., Moreira X., Zas R., Peñuelas J. 2012. Effects of phosphorus availability and genetic variation of leaf terpene content and emission rate in Pinus pinaster seedlings susceptible and resistant to the pine weevil, Hylobius abietis. Plant Biol. 14: 66-72.

Brus D.J., Hengeveld G.M., Walvoort D.J.J., Goedhart P.W., Heidema A.H., Nabuurs G.J., Gunia K. 2011: Statistical mapping of tree species over Europe. Eur. J. Forest Res. 131: 145-157.

Buchanan-Wollaston V., Page T., Harrison E., Breeze E., Lim P.O., Nam H.G., Lin J.F., Wu S.H., Swidzinski J., Ishizaki K., Leaver C.J. 2005. Comparative transcriptome analysis reveals significant differences in gene expression and signalling pathways between developmental and dark/starvationinduced senescence in Arabidopsis. Plant J. 42: 567-585.

Cohen-Kupiec R., Chet I., Cohen-Kupiec C. R. 1998. The molecular biology of chitin digestion. Curr. Opin. Biotechnol. 9: 270-277.

Creelman R.A., Mullet J.E. 1997. Biosynthesis and action of jasmonates in plants. Annu. Rev. Plant Physiol. Plant Mol. Biol. 48: 355-381.

Dubouzet J.G., Donaldson L., Black M.A., McNoe L., Liu V., Lloyd-Jones G. 2014. Heterologous hybridisation to a Pinus microarray: profiling of gene expression in Pinus radiata saplings exposed to ethephon. New Zealand J. Forestry Sci. 44: 21.

Duff S.M., Sarath G., Plaxton W.C. 1994. The role of acid phosphatases in plant phosphorus metabolism. Physiol. Plant. 90: 791-800.

Everaerts C., Grégoire J.C., Merlin J. 2012. The toxicity of Norway spruce monoterpenes to two bark beetle species and their associates. In: Mattson W.J., Levieux J., Bernard-Dagan C. (eds) Mechanisms of Woody Plant Defenses Against Insects. Springer, New York, pp. 335-344.

Farmer E.E., Ryan C.A. 1990. Interplant communication: airborne methyl jasmonate induces synthesis of proteinase inhibitors in plant leaves. Proc. Nat. Acad. Sci. USA 87: 7713-7716.

Fracetto G.G., Peres L.E., Mehdy M.C., Lambais M.R. 2013. Tomato ethylene mutants exhibit differences in arbuscular mycorrhiza development and levels of plant defense-related transcripts. Symbiosis 60: 155-167.

Franceschi V.R., Krekling T., Christiansen E. 2002. Application of MeJA on Picea abies (Pinaceae) stems induces defense-related responses in phloem and xylem. Am. J. Bot. 89: 578-586.

Hammerschmidt R. 1999. Induced disease resistance: how do induced plants stop pathogens? Physiol. Mol. Plant Pathol. 55: 77-84.

Hatfield R., Vermerris W. 2001. Lignin formation in plants. The dilemma of linkage specificity. Plant Physiol. 126: 1351-1357.

Hoth S., Morgante M., Sanchez J. P., Hanafey M.K., Tingey S.V., Chua N.H. 2002. Genome-wide gene expression profiling in Arabidopsis thaliana reveals new targets of abscisic acid and largely impaired gene regulation in the abi1-1 mutant. J. Cell Sci. 115: 4891-4900.

Hudgins J.W., Christiansen E., Franceschi V.R. 2003. MeJA induces changes mimicking anatomical defenses in diverse members of the Pinaceae. Tree Physiol. 23: 361-371.

Iseli B., Boller T., Neuhaus J.M. 1993. The N-terminal cysteinerich domain of tobacco class I chitinase is essential for chitin binding but not for catalytic or antifungal activity. Plant Physiol. 103: 221-226.

Kovach A., Wegrzyn J.L., Parra G., Holt C., Bruening G.E., Loopstra C.A., Hartigan J., Yandell M., Langley C.H., Korf I., Neale D.B. 2010. The Pinus taeda genome is characterized by diverse and highly diverged repetitive sequences. BMC Genomics 11: e1.

Liu Y., Liu M., Li X., Cao B., Ma X. 2014. Identification of differentially expressed genes in leaf of Reaumuria soongorica under PEG-induced drought stress by digital gene expression profiling. PloS One 9: e94277.

Lux-Endrich A., Treutter D., Feucht W.2000. Influence of nutrients and carbohydrate supply on the phenol composition of apple shoot cultures. Plant Cell Tissue Organ Cult. 60: 15-21.

Masón W.L., Alía R. 2000. Current and future status of Scots pine (Pinus sylvestris L.) forests in Europe. Forest Syst. 9: 317-335. 
Miller B., Madilao L.L., Ralph S., Bohlmann J., 2005. Insectinduced conifer defense. White pine weevil and MeJA induce traumatic resinosis, de novo formed volatile emissions, and accumulation of terpenoid synthase and putative octadecanoid pathway transcripts in Sitka spruce. Plant Physiol. 137: 369-382.

Montojo J., Zuberi K., Rodriguez H., Bader G.D., Morris Q. 2014. GeneMANIA: Fast gene network construction and function prediction for Cytoscape. F1000Research 3.

Morozova O., Marra M.A. 2008. Genomics Applications of nextgeneration sequencing technologies in functional genomics. Genomics 92: 255-264.

Moreira X., Sampedro L. Zas R., 2009. Defensive responses of Pinus pinaster seedlings to exogenous application of methyl jasmonate: concentration effect and systemic response. Environ. Exp. Bot. 67: 94-100.

Passarinho P.A., de Vries S.C. 2002. Arabidopsis chitinases: a genomic survey. The Arabidopsis Book 1: e0023.

Pham T., Chen H., Yu J., Dai L., Zhang R., Vu T. Q.T. 2014. The Differential effects of the blue-stain fungus Leptographium qinlingensis on monoterpenes and sesquiterpenes in the stem of Chinese white pine (Pinus armandi) saplings. Forests 5: 2730-2749.

Ralph S G., Yueh H., Friedmann M., Aeschliman D., Zeznik J.A., Nelson C.C., Butterfield Y.S., Kirkpatrick R., Liu J., Jones S.J., Marra M.A., Douglas C.J., Ritland K., Bohlmann J. 2006. Conifer defence against insects: microarray gene expression profiling of Sitka spruce (Picea sitchensis) induced by mechanical wounding or feeding by spruce budworms (Choristoneura occidentalis) or white pine weevils (Pissodes strobi) reveals large-scale changes of the host transcriptome. Plant Cell Environ. 29: 1545-1570.

Richardson D. M., Rundel P. W. 1998. Ecology and biogeography of Pinus: an introduction. In: Richardson D.M. (ed) Ecology and Biogeography of Pinus. Cambridge, Cambridge University Press, UK pp. 3-46.

Rubio-Piña J.A., Zapata-Pérez O. 2011. Isolation of total RNA from tissues rich in polyphenols and polysaccharides of mangrove plants. Electr. J. Biotechnol. 14: 11.

Sahai A.S., Manoch M.S. 1993. Chitinases of fungi and plants : their involvement in morphogenesis and host-parasite interaction. FEMS Microbiol. Rev. 11: 317-338.

Salmela M.J., Cavers S., Cottrell J.E., Iason G.R., Ennos R.A. 2013. Spring phenology shows genetic variation among and within populations in seedlings of Scots pine (Pinus sylvestris L.) in the Scottish Highlands. Plant Ecol. Divers. 6: 523-536.

Schenk G., Mitić N., Hanson G.R., Comba P. 2013. Purple acid phosphatase: A journey into the function and mechanism of a colorful enzyme. Coord. Chem. Rev. 257: 473-482.

Schlumbaum A., Mauch F., Vögeli U., Boller, T. 1986. Plant chitinases are potent inhibitors of fungal growth. Nature 324: 365-367.

Sevik H., Ayan S., Turna I., Yahyaoglu Z. 2010. Genetic diversity among populations in Scotch pine (Pinus sylvestris L.) seed stands of Western Black Sea Region in Turkey. African J. Biotechnol. 9: 7266-7272.

Shinshi H., Neuhaus J., Ryals J., Meins F. 1990. Structure of a tobacco endochitinase gene: evidence that different chitinase genes can arise by transposition of sequences encoding a cysteine-rich domain. Plant Mol. Biol. 14: 35-368.

Su Y., Xu L., Wang S., Wang Z., Yang Y., Chen Y., Que Y. 2015. Identification, phylogeny, and transcript of chitinase family genes in sugarcane. Sci. Rep. 5: srep10708.

Smith K. T. 2015. Compartmentalization, resource allocation, and wood quality. Curr. Forestry Rep. 1: 8-15.

Sun H., Paulin L., Alatalo E., Asiegbu F.O. 2011. Response of living tissues of Pinus sylvestris to the saprotrophic biocontrol fungus Phlebiopsis gigantea. Tree Physiol. 31: 438-451.

Škipars V., Krivmane B., Rungóis D. 2011. Thaumatin-like protein gene copy number variation in Scots pine (Pinus sylvestris). Environ. Exp. Biol. 9:75-81.

Vijayan P., Shockey J., Lévesque C.A., Cook R.J. 1998. A role for jasmonate in pathogen defense of Arabidopsis. Proc. Nat. Acad. Sci. USA 95: 7209-7214.

Wachowiak W., Trivedi U., Perry A., Cavers S. 2015. Comparative transcriptomics of a complex of four European pine species. BMC Genomics 16: 234.

Whetten R., Sederoff R., 1995. Lignin biosynthesis. Plant Cell 7: 1001.

Wink M. 1988. Plant breeding: importance of plant secondary metabolites for protection against pathogens and herbivores. Theor. Appl. Genet. 75: 225-233.

Yang G., Zhou R., Tang T., Shi S. 2008. Preparative biochemistry and biotechnology simple and efficient isolation of highquality total RNA from Hibiscus tiliaceus, a mangrove associate and its relatives. Prep. Biochem. Biotechnol. 38: 257-264.

Yaqoob N., Yakovlev I. A., Krokene P., Kvaalen H., Solheim H., Fossdal C.G. 2012. Defence-related gene expression in bark and sapwood of Norway spruce in response to Heterobasidion parviporum and methyl jasmonate. Physiol. Mol. Plant Pathol. 77: $10-16$.

Zas R., Björklund N., Nordlander G., Cendán C., Hellqvist C., Sampedro L. 2014. Exploiting jasmonate-induced responses for field protection of conifer seedlings against a major forest pest, Hylobius abietis. Forest Ecol. Manage. 313: 212-223. 
Appendix 1. Annotation of sequences differentially expressed between MeJA treated (Sm3, Sm4) and control (Sm5, Sm6, Sm7) libraries

\begin{tabular}{|c|c|c|c|c|c|c|c|c|c|c|}
\hline Reference sequence & Sm3 & Sm4 & Sm5 & Sm6 & Sm7 & $\log \mathrm{FC}$ & $\begin{array}{l}\text { PValue } \\
\text { fdr }\end{array}$ & Gene annotation & Organism & Accession No. \\
\hline comp43346_c0_seq1 & 250 & 96 & 0 & 0 & 0 & -9.62 & $3.68 \mathrm{E}-07$ & $\begin{array}{l}\text { Eukaryotic-type carbonic } \\
\text { anhydrase }\end{array}$ & $\begin{array}{l}\text { Medicago } \\
\text { truncatula }\end{array}$ & KEH16352.1 \\
\hline comp54078_c0_seq1 & 91 & 60 & 0 & 0 & 0 & -8.49 & $1.68 \mathrm{E}-07$ & Uninformative & & \\
\hline comp57289_c0_seq1 & 441 & 289 & 2 & 0 & 0 & -8.37 & 0.01 & Putative acid phosphatase & Pinus pinaster & CAC 84485.1 \\
\hline comp20846_c0_seq1 & 144 & 190 & 1 & 0 & 0 & -8.36 & $2.62 \mathrm{E}-06$ & $\begin{array}{l}\text { Alpha terpineol } \\
/ 1,8 \text {-cineole synthase }\end{array}$ & Pinus contorta & AFU73861.1 \\
\hline comp53497_c0_seq2 & 0 & 89 & 0 & 0 & 0 & -8.09 & 0.01 & Protein HOTHEAD & $\begin{array}{l}\text { Gossypium } \\
\text { arboreum }\end{array}$ & KHG26487.1 \\
\hline comp32018_c0_seq1 & 85 & 119 & 0 & 0 & 1 & -7.91 & $2.62 \mathrm{E}-06$ & $\begin{array}{l}\text { Alpha terpineol } \\
\text { /1,8-cineole synthase }\end{array}$ & Pinus contorta & AFU73861.1 \\
\hline comp55229_c0_seq9 & 47 & 59 & 0 & 0 & 0 & -7.8 & 0.01 & Chalcone synthase & Pinus pinaster & AAP85249.1 \\
\hline comp49218_c0_seq1 & 45 & 36 & 0 & 0 & 0 & -7.64 & $3.68 \mathrm{E}-07$ & $\begin{array}{l}\text { Isopentenyl diphosphate } \\
\text { isomerase }\end{array}$ & Pinus taeda & ACU56978.1 \\
\hline comp53497_c0_seq1 & 0 & 56 & 0 & 0 & 0 & -7.46 & 0.01 & Protein HOTHEAD & $\begin{array}{l}\text { Gossypium } \\
\text { arboreum }\end{array}$ & KHG26487.1 \\
\hline comp53815_c0_seq5 & 38 & 29 & 0 & 0 & 0 & -7.34 & 2.62E-06 & $\begin{array}{l}\text { Putative } \\
\text { metallophosphatase }\end{array}$ & Lupinus luteus & CAD12837.1 \\
\hline comp35142_c0_seq1 & 38 & 22 & 0 & 0 & 0 & -7.14 & 3.12E-06 & $\begin{array}{l}\text { Cinnamyl alcohol } \\
\text { acyltransferase } 1\end{array}$ & Larrea tridentata & АНА90802.1 \\
\hline comp1651716_c0_seq1 & 16 & 34 & 0 & 0 & 0 & -7.08 & 0 & $\begin{array}{l}\text { Jasmonate ZIM domain- } \\
\text { containing protein }\end{array}$ & $\begin{array}{l}\text { Sonneratia } \\
\text { caseolaris }\end{array}$ & AFU90898.1 \\
\hline comp48680_c0_seq2 & 5 & 39 & 0 & 0 & 0 & -7.04 & 0 & Laccase & Picea abies & AFV52381.1 \\
\hline comp54849_c0_seq17 & 89 & 70 & 1 & 0 & 0 & -7 & 0.01 & $\begin{array}{l}\text { Benzyl alcohol } \\
\text { O-benzoyltransferase }\end{array}$ & Morus notabilis & XP_010108951.1 \\
\hline comp210649_c0_seq1 & 25 & 20 & 0 & 0 & 0 & -6.78 & $8.21 \mathrm{E}-06$ & $\begin{array}{l}\text { Auxin-responsive family } \\
\text { protein }\end{array}$ & $\begin{array}{l}\text { Pseudotsuga } \\
\text { macrocarpa }\end{array}$ & ACH60220.1 \\
\hline comp53497_c0_seq3 & 0 & 80 & 0 & 0 & 1 & -6.75 & 0.01 & Protein HOTHEAD & $\begin{array}{l}\text { Gossypium } \\
\text { arboreum }\end{array}$ & KHG26487.1 \\
\hline comp53560_c0_seq1 & 0 & 39 & 0 & 0 & 0 & -6.75 & 0.04 & $\begin{array}{l}\text { Glyoxal oxidase-related } \\
\text { protein }\end{array}$ & Theobroma cacao & XP_007017716.1 \\
\hline comp50861_c0_seq1 & 23 & 72 & 0 & 1 & 0 & -6.75 & 0 & $\begin{array}{l}\text { Serine-type endopeptidase } \\
\text { inhibitor }\end{array}$ & $\begin{array}{l}\text { Arabidopsis } \\
\text { thaliana }\end{array}$ & NP_177351.1 \\
\hline comp47417_c0_seq1 & 42 & 4 & 0 & 0 & 0 & -6.6 & 0 & Isoeugenol synthase 1 & Glycine soja & KHN26455.1 \\
\hline comp53815_c0_seq1 & 36 & 6 & 0 & 0 & 0 & -6.48 & 0 & Purple acid phosphatase & Acacia mangium & BAO45898.1 \\
\hline comp56578_c0_seq1 & 74 & 52 & 0 & 0 & 2 & -6.42 & $3.68 \mathrm{E}-07$ & $\begin{array}{l}\text { Pathogen-inducible alpha- } \\
\text { dioxygenase }\end{array}$ & $\begin{array}{l}\text { Nicotiana } \\
\text { attenuata }\end{array}$ & AAG59584.1 \\
\hline comp47930_c0_seq1 & 52 & 34 & 0 & 1 & 0 & -6.41 & 0.01 & Uninformative & & \\
\hline comp243640_c0_seq1 & 26 & 10 & 0 & 0 & 0 & -6.32 & 0 & Cytochrome P450 71A1 & Morus notabilis & XP_010102947.1 \\
\hline comp54314_c0_seq1 & 13 & 53 & 0 & 0 & 1 & -6.26 & 0 & Class I chitinase & Pinus contorta & AEF59005.1 \\
\hline comp52953_c0_seq1 & 52 & 21 & 0 & 0 & 1 & -6.23 & $7.20 \mathrm{E}-06$ & Purple acid phosphatase & Acacia mangium & BAO45898.1 \\
\hline comp53900_c0_seq3 & 0 & 28 & 0 & 0 & 0 & -6.21 & 0.05 & $\begin{array}{l}\text { Kunitz type trypsin } \\
\text { inhibitor }\end{array}$ & $\begin{array}{l}\text { Medicago } \\
\text { truncatula }\end{array}$ & KEH38529.1 \\
\hline comp54934_c0_seq17 & 3 & 23 & 0 & 0 & 0 & -6.19 & 0.01 & Uninformative & & \\
\hline comp18977_c0_seq3 & 128 & 677 & 4 & 28 & 0 & -6.13 & 0.02 & Proline-rich protein & Pinus taeda & AAF75825.1 \\
\hline comp949065_c0_seq1 & 24 & 6 & 0 & 0 & 0 & -6.1 & 0 & $\begin{array}{l}\text { Protein-PII } \\
\text { uridylyltransferase }\end{array}$ & $\begin{array}{l}\text { Donghicola } \\
\text { xiamenensis }\end{array}$ & WP_028093236.1 \\
\hline comp52455_c0_seq6 & 28 & 5 & 0 & 0 & 0 & -6.08 & 0.01 & Amidase & Pseudomonas sp. & WP_008080115.1 \\
\hline comp54934_c0_seq15 & 5 & 20 & 0 & 0 & 0 & -6.07 & 0.01 & Uninformative & & \\
\hline comp1463951_c0_seq1 & 12 & 14 & 0 & 0 & 0 & -6.06 & 0 & $\begin{array}{l}\text { Sulfate/thiosulfate import } \\
\text { ATP-binding protein cysA }\end{array}$ & Theobroma cacao & XP_007049639.1 \\
\hline comp51296_c0_seq1 & 5 & 73 & 0 & 2 & 0 & -6.05 & 0 & $\begin{array}{l}\text { Glycoside hydrolase family } \\
71 \text { protein }\end{array}$ & $\begin{array}{l}\text { Heterobasidion } \\
\text { irregulare }\end{array}$ & XP_009545841.1 \\
\hline
\end{tabular}


Appendix 1. continued

\begin{tabular}{|c|c|c|c|c|c|c|c|c|c|c|}
\hline Reference sequence & Sm3 & Sm4 & Sm5 & Sm6 & $\operatorname{Sm} 7$ & $\log \mathrm{FC}$ & $\begin{array}{l}\text { PValue } \\
\text { fdr }\end{array}$ & Gene annotation & Organism & Accession No. \\
\hline comp107485_c0_seq1 & 14 & 12 & 0 & 0 & 0 & -5.99 & 0 & $\begin{array}{l}\text { S-adenosyl-L- } \\
\text { methionine-dependent } \\
\text { methyltransferases } \\
\text { superfamily protein }\end{array}$ & Theobroma cacao & XP_007048464.1 \\
\hline comp35518_c0_seq1 & 31 & 0 & 0 & 0 & 0 & -5.98 & 0.05 & Neutral invertase & $\begin{array}{l}\text { Viscum album } \\
\text { subsp. album }\end{array}$ & ABF50710.1 \\
\hline comp375741_c0_seq1 & 26 & 2 & 0 & 0 & 0 & -5.92 & 0.01 & $\begin{array}{l}\text { 1-deoxy-D-xylulose } \\
5 \text {-phosphate synthase } \\
\text { type II }\end{array}$ & Picea abies & ABS50520.1 \\
\hline comp55263_c1_seq19 & 2 & 18 & 0 & 0 & 0 & -5.9 & 0.03 & $\begin{array}{l}\text { Pentatricopeptide (PPR) } \\
\text { repeat protein }\end{array}$ & $\begin{array}{l}\text { Medicago } \\
\text { truncatula }\end{array}$ & КEH25607.1 \\
\hline comp54934_c0_seq10 & 2 & 20 & 0 & 0 & 0 & -5.89 & 0.02 & Uninformative & & \\
\hline comp494061_c0_seq1 & 4 & 18 & 0 & 0 & 0 & -5.86 & 0.01 & $\begin{array}{l}\text { Chromatin assembly factor } \\
1 \text { subunit A }\end{array}$ & Theobroma cacao & XP_007049998.1 \\
\hline comp54849_c0_seq11 & 49 & 23 & 1 & 0 & 0 & -5.81 & 0.04 & $\begin{array}{l}\text { Benzyl alcohol } \\
\text { O-benzoyltransferase }\end{array}$ & Morus notabilis & XP_010108951.1 \\
\hline comp52965_c0_seq1 & 12 & 12 & 0 & 0 & 0 & -5.79 & 0.02 & $\begin{array}{l}\text { Inositol-pentakisphosphate } \\
\text { 2-kinase-like protein }\end{array}$ & $\begin{array}{l}\text { Medicago } \\
\text { truncatula }\end{array}$ & KEH36181.1 \\
\hline comp49393_c0_seq1 & 32 & 85 & 0 & 0 & 4 & -5.75 & $8.36 \mathrm{E}-05$ & $\begin{array}{l}\text { Clavaminate synthase-like } \\
\text { protein }\end{array}$ & Aegilops tauschii & EMT27634.1 \\
\hline comp1228066_c0_seq1 & 53 & 29 & 1 & 0 & 1 & -5.68 & $1.25 \mathrm{E}-05$ & $\begin{array}{l}\text { GDSL-like lipase/ } \\
\text { Acylhydrolase superfamily } \\
\text { protein, putative isoform } 1\end{array}$ & Theobroma cacao & XP_007027683.1 \\
\hline comp54934_c0_seq16 & 6 & 37 & 0 & 0 & 1 & -5.65 & 0.01 & Uninformative & & \\
\hline comp27055_c0_seq1 & 48 & 32 & 2 & 0 & 0 & -5.62 & 7.65E-06 & $\begin{array}{l}\text { 1-deoxy-D-xylulose } \\
5 \text {-phosphate synthase } \\
\text { type II }\end{array}$ & Picea abies & ABS50520.1 \\
\hline comp52828_c0_seq2 & 2 & 33 & 0 & 0 & 1 & -5.57 & 0.01 & Heat shock protein & $\begin{array}{l}\text { Ammopiptanthus } \\
\text { mongolicus }\end{array}$ & AFC01202.1 \\
\hline comp36780_c0_seq1 & 36 & 14 & 0 & 1 & 0 & -5.57 & 0.04 & $\begin{array}{l}\text { Jasmonate-zim-domain } \\
\text { protein } 1\end{array}$ & Theobroma cacao & XP_007012594.1 \\
\hline comp40675_c0_seq2 & 10 & 10 & 0 & 0 & 0 & -5.57 & 0.02 & $\begin{array}{l}\mathrm{ABC}-2 \text { and Plant PDR } \\
\mathrm{ABC} \text {-type transporter } \\
\text { family protein isoform } 5\end{array}$ & Theobroma cacao & XP_007024298.1 \\
\hline comp45469_c0_seq4 & 5 & 12 & 0 & 0 & 0 & -5.53 & 0.02 & $\begin{array}{l}\text { Putative LRR receptor-like } \\
\text { serine/threonine-protein } \\
\text { kinase }\end{array}$ & Morus notabilis & XP_010092221.1 \\
\hline comp54143_c1_seq4 & 10 & 8 & 0 & 0 & 0 & -5.46 & 0 & Uninformative & & \\
\hline comp42728_c1_seq1 & 6 & 10 & 0 & 0 & 0 & -5.37 & 0.03 & $\begin{array}{l}\text { Sn1-specific diacylglycerol } \\
\text { lipase alpha }\end{array}$ & $\begin{array}{l}\text { Gossypium } \\
\text { arboreum }\end{array}$ & KHG05530.1 \\
\hline comp431420_c0_seq1 & 26 & 12 & 0 & 0 & 1 & -5.34 & 0 & $\begin{array}{l}\text { PTI1-like tyrosine-protein } \\
\text { kinase }\end{array}$ & Glycine soja & KHN31557.1 \\
\hline comp44918_c0_seq1 & 16 & 2 & 0 & 0 & 0 & -5.32 & 0.03 & Uninformative & & \\
\hline comp68888_c0_seq1 & 12 & 40 & 0 & 0 & 2 & -5.29 & 0 & Thaumatin-like protein & Pinus sylvestris & АHН02776.1 \\
\hline comp47732_c0_seq1 & 0 & 55 & 0 & 2 & 1 & -5.28 & 0.03 & Asparagine synthetase & Pinus pinaster & ADU02856.1 \\
\hline comp40057_c0_seq1 & 4 & 10 & 0 & 0 & 0 & -5.26 & 0.03 & Uninformative & & \\
\hline comp19537_c0_seq1 & 6 & 9 & 0 & 0 & 0 & -5.24 & 0.05 & Uninformative & & \\
\hline comp39760_c0_seq1 & 42 & 18 & 2 & 0 & 0 & -5.23 & 0 & Cinnamoyl CoA reductase & $\begin{array}{l}\text { Arabidopsis } \\
\text { thaliana }\end{array}$ & AAM62475.1 \\
\hline comp46327_c0_seq1 & 31 & 6 & 0 & 0 & 1 & -5.19 & 0 & Uuninformative & & \\
\hline comp50304_c0_seq1 & 9 & 49 & 0 & 2 & 1 & -5.19 & 0 & Response to low sulfur 3 & Theobroma cacao & XP_007039253.1 \\
\hline comp23260_c0_seq1 & 14 & 2 & 0 & 0 & 0 & -5.19 & 0.03 & Uninformative & & \\
\hline comp52065_c1_seq6 & 9 & 6 & 0 & 0 & 0 & -5.17 & 0.01 & $\begin{array}{l}\text { Tetratricopeptide repeat } \\
\text { (TPR)-like superfamily } \\
\text { protein isoform } 1\end{array}$ & Theobroma cacao & XP_007036762.1 \\
\hline
\end{tabular}


Appendix 1. continued

\begin{tabular}{|c|c|c|c|c|c|c|c|c|c|c|}
\hline Reference sequence & Sm3 & Sm 4 & Sm5 & Sm6 & $\mathrm{Sm} 7$ & $\log \mathrm{FC}$ & $\begin{array}{c}\text { PValue } \\
\text { fdr }\end{array}$ & Gene annotation & Organism & Accession No. \\
\hline comp54849_c0_seq5 & 47 & 68 & 1 & 5 & 0 & -5.17 & 0.03 & $\begin{array}{l}\text { Benzoyl CoA benzoic acid } \\
\text { benzoyltransferase }\end{array}$ & Verbena $x$ hybrida & BAE72881.1 \\
\hline comp46741_c0_seq1 & 81 & 70 & 2 & 0 & 5 & -5.14 & $1.08 \mathrm{E}-05$ & Arogenate dehydratase 3 & Petunia $x$ hybrida & ACY79504.1 \\
\hline comp54246_c0_seq2 & 12 & 3 & 0 & 0 & 0 & -5.13 & 0.02 & NBS/LRR & Pinus taeda & AAM28912.1 \\
\hline comp54934_c0_seq7 & 10 & 21 & 1 & 0 & 0 & -5.12 & 0 & Uninformative & & \\
\hline comp55507_c0_seq1 & 50 & 102 & 0 & 0 & 9 & -5.11 & 0 & Class III peroxidase PSYP1 & Pinus sylvestris & AAG02215.1 \\
\hline comp49725_c0_seq6 & 5 & 8 & 0 & 0 & 0 & -5.07 & 0.03 & $\begin{array}{l}\text { Calmodulin binding } \\
\text { protein }\end{array}$ & Ricinus communis & XP_002517079.1 \\
\hline comp45618_c0_seq1 & 8 & 5 & 0 & 0 & 0 & -4.98 & 0.01 & $\begin{array}{l}\text { Putative truncated TIR- } \\
\text { NBS-LRR protein }\end{array}$ & Pinus monticola & ADW94528.1 \\
\hline comp25629_c0_seq1 & 26 & 30 & 0 & 1 & 2 & -4.92 & $6.15 \mathrm{E}-05$ & JAZ10 & $\begin{array}{l}\text { Gossypium } \\
\text { barbadense }\end{array}$ & AJT58397.1 \\
\hline comp184252_c0_seq1 & 6 & 18 & 0 & 0 & 1 & -4.91 & 0.01 & $\begin{array}{l}\mathrm{C} 2 \mathrm{H} 2 \text {-like zinc finger } \\
\text { protein }\end{array}$ & Theobroma cacao & XP_007021715.1 \\
\hline comp49872_c0_seq2 & 5 & 6 & 0 & 0 & 0 & -4.81 & 0.05 & F-box/LRR-repeat protein & $\begin{array}{l}\text { Pediculus } \\
\text { humanus corporis }\end{array}$ & XP_002429423.1 \\
\hline comp37005_c0_seq1 & 5 & 6 & 0 & 0 & 0 & -4.79 & 0.04 & Plant IF-like protein & $\begin{array}{l}\text { Medicago } \\
\text { truncatula }\end{array}$ & KEH43124.1 \\
\hline comp39224_c0_seq1 & 13 & 17 & 1 & 0 & 0 & -4.78 & 0.05 & Peroxidase & Picea abies & CAH10839.1 \\
\hline comp54766_c0_seq16 & 7 & 4 & 0 & 0 & 0 & -4.75 & 0.04 & $\begin{array}{l}\text { Progesterone 5-beta- } \\
\text { reductase }\end{array}$ & $\begin{array}{l}\text { Gomphocarpus } \\
\text { fruticosus }\end{array}$ & ADG56546.1 \\
\hline comp53815_c0_seq4 & 31 & 10 & 0 & 0 & 2 & -4.75 & 0 & Purple acid phosphatase & Acacia mangium & BAO45898.1 \\
\hline comp407480_c0_seq1 & 33 & 8 & 0 & 2 & 0 & -4.74 & 0 & $\begin{array}{l}\mathrm{ABC} \text { transporter G family } \\
\text { member } 36\end{array}$ & $\begin{array}{l}\text { Gossypium } \\
\text { arboreum }\end{array}$ & KHG28037.1 \\
\hline comp50861_c0_seq2 & 21 & 54 & 1 & 3 & 1 & -4.71 & 0.02 & $\begin{array}{l}\text { Serine-type endopeptidase } \\
\text { inhibitor }\end{array}$ & $\begin{array}{l}\text { Arabidopsis lyrata } \\
\text { subsp. lyrata }\end{array}$ & XP_002887410.1 \\
\hline comp49971_c1_seq1 & 27 & 19 & 0 & 3 & 0 & -4.66 & $3.17 \mathrm{E}-05$ & PAR1 protein & Theobroma cacao & XP_007026832.1 \\
\hline comp54934_c0_seq6 & 3 & 29 & 0 & 0 & 2 & -4.66 & 0.05 & Uninformative & & \\
\hline comp52407_c0_seq1 & 104 & 76 & 1 & 2 & 10 & -4.62 & 0 & $\begin{array}{l}\text { Putative flavoprotein- } \\
\text { containing polyamine } \\
\text { oxidase }\end{array}$ & Pinus sylvestris & 7306.1 \\
\hline comp48744_c0_seq1 & 22 & 16 & 1 & 0 & 1 & -4.6 & 0 & $\begin{array}{l}\text { Dehydrodolichyl } \\
\text { diphosphate synthase } 6\end{array}$ & Zea mays & ACG35019.1 \\
\hline comp35804_c0_seq1 & 26 & 10 & 0 & 1 & 1 & -4.58 & 0 & $\begin{array}{l}\text { Helix-loop-helix DNA- } \\
\text { binding domain containing } \\
\text { protein }\end{array}$ & $\begin{array}{l}\text { Oryza sativa } \\
\text { Japonica Group }\end{array}$ & ABF97395.1 \\
\hline comp53918_c0_seq1 & 6 & 33 & 1 & 2 & 0 & -4.57 & 0.01 & PREDICTED: pinin & Cucumis melo & XP_008453065.1 \\
\hline comp51065_c0_seq1 & 26 & 11 & 0 & 2 & 0 & -4.55 & 0.01 & Peroxidase & Picea abies & CAD92856.1 \\
\hline comp18977_c0_seq4 & 100 & 102 & 1 & 21 & 0 & -4.54 & 0.03 & Proline-rich protein & Pinus taeda & AAF75825.1 \\
\hline comp18977_c0_seq1 & 120 & 76 & 0 & 20 & 1 & -4.54 & 0.04 & Proline-rich protein & Pinus taeda & AAF75825.1 \\
\hline comp54314_c0_seq4 & 11 & 41 & 0 & 5 & 0 & -4.49 & 0.01 & Class I chitinase & Pinus contorta & AEF59005.1 \\
\hline comp50147_c0_seq3 & 67 & 70 & 4 & 0 & 6 & -4.47 & 0 & $\begin{array}{l}\text { Pyrroline-5-carboxylate } \\
\text { synthetase isoform } 3\end{array}$ & Theobroma cacao & XP_007009201.1 \\
\hline comp52043_c1_seq2 & 54 & 99 & 6 & 5 & 0 & -4.47 & 0.02 & Embryo-abundant protein & Picea glauca & AAB01567.1 \\
\hline comp54813_c0_seq2 & 90 & 375 & 7 & 57 & 0 & -4.46 & 0.05 & PR-1 & Solanum torvum & BAB78476.1 \\
\hline comp18977_c0_seq2 & 127 & 95 & 1 & 25 & 0 & -4.44 & 0.04 & Proline-rich protein & Pinus taeda & AAF75825.1 \\
\hline comp51867_c0_seq3 & 29 & 6 & 1 & 0 & 1 & -4.44 & 0.01 & Beta-lactamase & $\begin{array}{l}\text { Aquimarina } \\
\text { macrocephali }\end{array}$ & WP_024768563.1 \\
\hline comp40759_c0_seq1 & 42 & 37 & 5 & 0 & 0 & -4.43 & 0 & Uninformative & & \\
\hline comp39422_c0_seq1 & 18 & 3 & 0 & 0 & 1 & -4.39 & 0.03 & $\begin{array}{l}\text { Pathogenesis-related } \\
\text { homeodomain protein }\end{array}$ & $\begin{array}{l}\text { Medicago } \\
\text { truncatula }\end{array}$ & XP_003595073.1 \\
\hline comp236525_c0_seq1 & 33 & 2 & 0 & 0 & 2 & -4.38 & 0.02 & $\begin{array}{l}\text { Zinc transporter } 11 \text {-like } \\
\text { protein }\end{array}$ & $\begin{array}{l}\text { Gossypium } \\
\text { arboreum }\end{array}$ & KHG22377.1 \\
\hline comp38640_c1_seq1 & 5 & 28 & 0 & 0 & 3 & -4.32 & 0.02 & Putative S-acyltransferase & Glycine soja & KHN33780.1 \\
\hline
\end{tabular}


Appendix 1. continued

\begin{tabular}{|c|c|c|c|c|c|c|c|c|c|c|}
\hline Reference sequence & Sm3 & Sm4 & Sm5 & Sm6 & Sm7 & $\log \mathrm{FC}$ & $\begin{array}{c}\text { PValue } \\
\text { fdr }\end{array}$ & Gene annotation & Organism & Accession No. \\
\hline comp31109_c0_seq1 & 10 & 8 & 0 & 0 & 1 & -4.32 & 0 & $\begin{array}{l}\text { Pentatricopeptide repeat- } \\
\text { containing protein, } \\
\text { putative isoform } 1\end{array}$ & Theobroma cacao & XP_007010632.1 \\
\hline comp52761_c0_seq3 & 148 & 58 & 0 & 25 & 1 & -4.31 & 0.01 & PDR1 & Picea abies & ADP55080.1 \\
\hline comp47422_c0_seq1 & 10 & 18 & 2 & 0 & 0 & -4.29 & 0.02 & $\begin{array}{l}\text { Primary amine oxidase } \\
\text { isoform } 2\end{array}$ & Theobroma cacao & XP_007034733.1 \\
\hline comp53815_c0_seq2 & 29 & 5 & 2 & 0 & 0 & -4.28 & 0.02 & Purple acid phosphatase & Acacia mangium & BAO45898.1 \\
\hline comp52274_c3_seq6 & 16 & 3 & 0 & 0 & 1 & -4.27 & 0.05 & $\begin{array}{l}\text { L-type lectin-domain } \\
\text { receptor kinase S. } 4\end{array}$ & $\begin{array}{l}\text { Medicago } \\
\text { truncatula }\end{array}$ & КEH22964.1 \\
\hline comp48217_c0_seq1 & 30 & 86 & 0 & 12 & 5 & -4.27 & 0 & $\begin{array}{l}\text { Putative peptide/nitrate } \\
\text { transporter }\end{array}$ & Morus notabilis & XP_010088558.1 \\
\hline comp49431_c0_seq1 & 19 & 9 & 0 & 0 & 2 & -4.24 & 0 & $\begin{array}{l}\text { Double-stranded RNA- } \\
\text { binding protein } 5\end{array}$ & Morus notabilis & XP_010110932.1 \\
\hline comp54964_c0_seq3 & 4 & 26 & 0 & 0 & 3 & -4.23 & 0.03 & $\begin{array}{l}\text { Major facilitator } \\
\text { superfamily protein }\end{array}$ & Theobroma cacao & XP_007028238.1 \\
\hline comp54087_c0_seq1 & 14 & 4 & 0 & 0 & 1 & -4.22 & 0.01 & Dynein beta chain, ciliary & $\begin{array}{l}\text { Gossypium } \\
\text { arboreum }\end{array}$ & KHG15580.1 \\
\hline comp55592_c0_seq3 & 23 & 14 & 1 & 0 & 2 & -4.19 & 0 & $\begin{array}{l}\text { Serine/threonine protein } \\
\text { kinase isolog }\end{array}$ & $\begin{array}{l}\text { Arabidopsis } \\
\text { thaliana }\end{array}$ & AAM20520.1 \\
\hline comp54494_c0_seq1 & 8 & 16 & 0 & 0 & 2 & -4.19 & 0.01 & $\begin{array}{l}\mathrm{C} 2 \mathrm{H} 2 \text {-like zinc finger } \\
\text { protein }\end{array}$ & Theobroma cacao & XP_007045432.1 \\
\hline comp45452_c0_seq1 & 16 & 19 & 0 & 0 & 3 & -4.14 & 0.01 & LOB domain protein 1 & $\begin{array}{l}\text { Solanum } \\
\text { demissum }\end{array}$ & AAT40528.1 \\
\hline comp3590_c0_seq1 & 8 & 8 & 0 & 0 & 1 & -4.13 & 0.02 & Uninformative & & \\
\hline comp55572_c0_seq8 & 10 & 6 & 1 & 0 & 0 & -4.11 & 0.02 & $\begin{array}{l}\text { Pentatricopeptide repeat- } \\
\text { containing -like protein }\end{array}$ & $\begin{array}{l}\text { Gossypium } \\
\text { arboreum }\end{array}$ & KHG29369.1 \\
\hline comp53352_c0_seq2 & 10 & 6 & 1 & 0 & 0 & -4.1 & 0.02 & $\begin{array}{l}\text { SWI/SNF complex subunit } \\
\text { SMARCC2 }\end{array}$ & $\begin{array}{l}\text { Medicago } \\
\text { truncatula }\end{array}$ & XP_003602787.1 \\
\hline comp14610_c0_seq1 & 79 & 14 & 1 & 2 & 6 & -4.05 & 0 & Triacylglycerol lipase & Ricinus communis & XP_002513514.1 \\
\hline comp29578_c0_seq1 & 12 & 10 & 0 & 0 & 2 & -3.98 & 0.01 & Cytochrome P450 & $\begin{array}{l}\text { Medicago } \\
\text { truncatula }\end{array}$ & XP_003607255.1 \\
\hline comp40102_c0_seq1 & 54 & 51 & 8 & 0 & 1 & -3.98 & 0 & $\begin{array}{l}\text { Dihydroflavonol-4- } \\
\text { reductase }\end{array}$ & Ginkgo biloba & AGR34043 \\
\hline comp43206_c0_seq1 & 16 & 8 & 2 & 0 & 0 & -3.98 & 0.01 & $\begin{array}{l}\text { Chromatin assembly factor } \\
1 \text { subunit A-B }\end{array}$ & $\begin{array}{l}\text { Gossypium } \\
\text { arboreum }\end{array}$ & KHG13021.1 \\
\hline comp38971_c0_seq2 & 10 & 13 & 2 & 0 & 0 & -3.95 & 0.03 & $\begin{array}{l}\text { Plant neutral invertase } \\
\text { family protein isoform } 1\end{array}$ & Theobroma cacao & XP_007041939.1 \\
\hline comp54755_c0_seq16 & 56 & 60 & 2 & 14 & 1 & -3.91 & 0.05 & $\begin{array}{l}\text { 2-methyl-3-buten-2-ol } \\
\text { synthase }\end{array}$ & Pinus greggii & AFJ73549.1 \\
\hline comp42778_c0_seq1 & 10 & 16 & 0 & 0 & 3 & -3.86 & 0.01 & Lipase & $\begin{array}{l}\text { Medicago } \\
\text { truncatula }\end{array}$ & KEH44038.1 \\
\hline comp25525_c0_seq1 & 24 & 10 & 0 & 4 & 0 & -3.85 & 0 & JAZ10 & $\begin{array}{l}\text { Gossypium } \\
\text { barbadense }\end{array}$ & AJT58397.1 \\
\hline comp44305_c0_seq1 & 11 & 22 & 1 & 2 & 1 & -3.83 & 0 & $\begin{array}{l}\text { Putative quinone } \\
\text { oxidoreductase-like protein }\end{array}$ & $\begin{array}{l}\text { Gardenia } \\
\text { jasminoides }\end{array}$ & AIX10953.1 \\
\hline comp49135_c0_seq2 & 17 & 17 & 3 & 0 & 0 & -3.82 & 0.04 & Antimicrobial peptide 1 & Pinus sylvestris & AAL05052.1 \\
\hline comp45534_c0_seq1 & 159 & 183 & 17 & 18 & 8 & -3.79 & 0.01 & $\begin{array}{l}\text { Phenylalanine ammonia- } \\
\text { lyase }\end{array}$ & Pinus sylvestris & AAL74331.1 \\
\hline comp16981_c0_seq1 & 7 & 15 & 0 & 3 & 0 & -3.78 & 0.02 & $\begin{array}{l}\text { Heavy metal transport/ } \\
\text { detoxification superfamily } \\
\text { protein }\end{array}$ & Theobroma cacao & XP_007050858.1 \\
\hline comp569_c0_seq1 & 16 & 31 & 2 & 0 & 4 & -3.78 & 0.01 & $\begin{array}{l}\text { WRKY family } \\
\text { transcription factor }\end{array}$ & $\begin{array}{l}\text { Medicago } \\
\text { truncatula }\end{array}$ & KEH20878.1 \\
\hline comp26588_c0_seq1 & 12 & 6 & 0 & 2 & 0 & -3.72 & 0 & $\begin{array}{l}\text { Cellulose-synthase-like } \\
\text { C12 }\end{array}$ & Theobroma cacao & XP_007018423.1 \\
\hline
\end{tabular}


Appendix 1. continued

\begin{tabular}{|c|c|c|c|c|c|c|c|c|c|c|}
\hline Reference sequence & Sm3 & Sm4 & Sm5 & Sm6 & Sm7 & $\log \mathrm{FC}$ & $\begin{array}{l}\text { PValue } \\
\text { fdr }\end{array}$ & Gene annotation & Organism & Accession No. \\
\hline comp54636_c0_seq21 & 8 & 4 & 0 & 1 & 0 & -3.72 & 0.04 & $\begin{array}{l}\text { Putative reverse } \\
\text { transcriptase }\end{array}$ & Arachis hypogaea & ACN78497.1 \\
\hline comp52692_c0_seq1 & 8 & 4 & 0 & 0 & 1 & -3.72 & 0.02 & $\begin{array}{l}\text { Similar to RPS-2 disease } \\
\text { resistance protein }\end{array}$ & $\begin{array}{l}\text { Arabidopsis } \\
\text { thaliana }\end{array}$ & AAK96709.1 \\
\hline comp51409_c0_seq1 & 49 & 17 & 1 & 0 & 7 & -3.7 & 0.01 & Cytochrome P450 71A1 & Morus notabilis & XP_010099912.1 \\
\hline comp34441_c0_seq1 & 14 & 16 & 0 & 2 & 2 & -3.7 & 0 & $\begin{array}{l}\text { R2R3-MYB transcription } \\
\text { factor MYB11 }\end{array}$ & Picea glauca & ABD60286.2 \\
\hline comp55437_c0_seq1 & 565 & 687 & 31 & 177 & 35 & -3.68 & 0 & Carbonic anhydrase & Ricinus communis & XP_002529418.1 \\
\hline comp47738_c0_seq1 & 18 & 14 & 3 & 1 & 0 & -3.66 & 0.01 & Laccase 1 & Theobroma cacao & XP_007036761.1 \\
\hline comp52474_c0_seq10 & 31 & 4 & 0 & 0 & 4 & -3.65 & 0.05 & $\begin{array}{l}\text { Plant-specific domain } \\
\text { TIGR01589 family protein }\end{array}$ & $\begin{array}{l}\text { Medicago } \\
\text { truncatula }\end{array}$ & XP_003621784.1 \\
\hline comp45295_c0_seq1 & 161 & 55 & 11 & 10 & 5 & -3.64 & 0.01 & $\begin{array}{l}\text { Cinnamoyl-CoA reductase } \\
1\end{array}$ & Betula platyphylla & AIX92145.1 \\
\hline comp44346_c0_seq2 & 5 & 6 & 0 & 0 & 1 & -3.63 & 0.04 & $\begin{array}{l}\text { PREDICTED: } \\
\text { uncharacterized protein } \\
\text { ycf } 45 \text { isoform X1 }\end{array}$ & $\begin{array}{l}\text { Nicotiana } \\
\text { tomentosiformis }\end{array}$ & XP_009631320.1 \\
\hline comp77850_c0_seq1 & 26 & 8 & 2 & 0 & 2 & -3.61 & 0.01 & $\begin{array}{l}\text { myb-like HTH } \\
\text { transcriptional regulator } \\
\text { family protein }\end{array}$ & $\begin{array}{l}\text { Arabidopsis } \\
\text { thaliana }\end{array}$ & NP_973385.1 \\
\hline comp32428_c1_seq1 & 631 & 385 & 39 & 126 & 17 & -3.61 & 0 & $\begin{array}{l}\text { 3-deoxy-D-arabino- } \\
\text { heptulosonate 7-phosphate } \\
\text { synthase }\end{array}$ & Picea abies & AET43997.1 \\
\hline comp52474_c0_seq1 & 4 & 53 & 3 & 3 & 4 & -3.6 & 0.03 & $\begin{array}{l}\text { Plant-specific domain } \\
\text { TIGR01589 family protein }\end{array}$ & $\begin{array}{l}\text { Medicago } \\
\text { truncatula }\end{array}$ & XP_003621784.1 \\
\hline comp46505_c1_seq1 & 13 & 5 & 1 & 0 & 1 & -3.6 & 0.02 & DNA repair protein & $\begin{array}{l}\text { Aphanomyces } \\
\text { invadans }\end{array}$ & XP_008869217.1 \\
\hline comp54314_c0_seq5 & 13 & 43 & 0 & 6 & 4 & -3.58 & 0.01 & Class I chitinase & Pinus contorta & AEF59005.1 \\
\hline comp55573_c0_seq5 & 198 & 77 & 7 & 5 & 28 & -3.58 & 0.01 & $\begin{array}{l}\text { Serine carboxypeptidase- } \\
\text { like } 20\end{array}$ & Morus notabilis & XP_010095610.1 \\
\hline comp48058_c0_seq1 & 14 & 10 & 2 & 0 & 1 & -3.58 & 0.02 & $\begin{array}{l}\text { TPA: calmodulin-binding } \\
\text { heat-shock protein }\end{array}$ & Zea mays & DAA39600.1 \\
\hline comp52473_c0_seq1 & 17 & 8 & 1 & 0 & 2 & -3.58 & 0.01 & $\begin{array}{l}\text { Dormancy/auxin } \\
\text { associated-like protein }\end{array}$ & Picea sitchensis & ADP94909.1 \\
\hline comp42341_c0_seq1 & 52 & 32 & 5 & 0 & 6 & -3.56 & 0 & $\begin{array}{l}\text { Acireductone dioxygenase } \\
\text { family protein }\end{array}$ & $\begin{array}{l}\text { Populus } \\
\text { trichocarpa }\end{array}$ & XP_002311641.1 \\
\hline comp4637_c0_seq1 & 21 & 8 & 0 & 2 & 2 & -3.55 & 0.01 & $\begin{array}{l}\text { ABC-2 and Plant PDR } \\
\text { ABC-type transporter } \\
\text { family protein isoform } 1\end{array}$ & Theobroma cacao & XP_007024294.1 \\
\hline comp37103_c0_seq1 & 13 & 14 & 0 & 2 & 2 & -3.52 & 0.01 & $\begin{array}{l}\text { PREDICTED: pollen- } \\
\text { specific leucine-rich repeat } \\
\text { extensin-like protein } 3\end{array}$ & Brassica rapa & XP_009106541.1 \\
\hline comp32319_c0_seq1 & 583 & 320 & 66 & 29 & 13 & -3.52 & 0.02 & Bark storage protein $\mathrm{A}$ & Glycine soja & KHN20661.1 \\
\hline comp404334_c0_seq1 & 10 & 6 & 0 & 1 & 1 & -3.49 & 0.02 & $\begin{array}{l}\text { Putative TIR-NBS-LRR } \\
\text { protein }\end{array}$ & Pinus monticola & ADW94527.1 \\
\hline comp46803_c0_seq3 & 10 & 6 & 0 & 0 & 2 & -3.44 & 0.05 & Uninformative & & \\
\hline comp55665_c0_seq12 & 14 & 8 & 0 & 0 & 3 & -3.41 & 0.05 & Glutaredoxin & Cucumis sativus & AGX01496.1 \\
\hline comp52043_c1_seq1 & 11 & 30 & 2 & 3 & 2 & -3.4 & 0.03 & Embryo-abundant protein & Picea glauca & АAB01567.1 \\
\hline comp42931_c0_seq1 & 49 & 32 & 9 & 0 & 1 & -3.4 & 0.01 & $\begin{array}{l}\text { Phospholipase A1- } \\
\text { Igammal }\end{array}$ & $\begin{array}{l}\text { Arabidopsis } \\
\text { thaliana }\end{array}$ & NP_849603.1 \\
\hline comp47676_c0_seq1 & 32 & 44 & 4 & 2 & 7 & -3.4 & 0 & $\begin{array}{l}\text { Phospholipase A1- } \\
\text { Igamma3 }\end{array}$ & Morus notabilis & XP_010102366.1 \\
\hline comp54725_c0_seq10 & 8 & 17 & 1 & 2 & 1 & -3.39 & 0.03 & $\begin{array}{l}\text { S-adenosyl-L- } \\
\text { methionine-dependent } \\
\text { methyltransferases } \\
\text { superfamily protein }\end{array}$ & Theobroma cacao & XP_007048464.1 \\
\hline
\end{tabular}


Appendix 1. continued

\begin{tabular}{|c|c|c|c|c|c|c|c|c|c|c|}
\hline Reference sequence & Sm3 & Sm4 & Sm5 & Sm6 & $\operatorname{Sm} 7$ & $\log \mathrm{FC}$ & $\begin{array}{c}\text { PValue } \\
\text { fdr }\end{array}$ & Gene annotation & Organism & Accession No. \\
\hline comp46913_c0_seq1 & 15 & 5 & 0 & 2 & 1 & -3.38 & 0.02 & $\begin{array}{l}\text { Plasma membrane-like } \\
\text { protein isoform } 1\end{array}$ & Theobroma cacao & XP_007051655.1 \\
\hline comp54700_c0_seq1 & 20 & 28 & 0 & 0 & 9 & -3.36 & 0.03 & Ethylene response factor 14 & Actinidia deliciosa & ADJ67443.1 \\
\hline comp54817_c0_seq1 & 347 & 634 & 33 & 167 & 48 & -3.35 & 0.01 & Class VII chitinase & Pinus contorta & AEF59008.1 \\
\hline comp41510_c0_seq1 & 16 & 13 & 1 & 2 & 2 & -3.34 & 0.01 & $\begin{array}{l}\text { Protein-tyrosine } \\
\text { phosphatase mitochondrial } \\
\text { 1-like protein }\end{array}$ & Morus notabilis & XP_010104857.1 \\
\hline comp53534_c0_seq5 & 10 & 14 & 2 & 2 & 0 & -3.34 & 0.03 & $\begin{array}{l}\text { Ramosal enhancer locus } \\
2 \text { protein }\end{array}$ & $\begin{array}{l}\text { Phacelurus } \\
\text { digitatus }\end{array}$ & AFJ42403.1 \\
\hline comp48963_c0_seq1 & 18 & 13 & 2 & 0 & 3 & -3.33 & 0.01 & $\begin{array}{l}\text { Surfeit locus } 1 \text { cytochrome } \\
\text { c oxidase biogenesis } \\
\text { protein isoform } 1\end{array}$ & Theobroma cacao & XP_007036878.1 \\
\hline comp54624_c1_seq2 & 24 & 44 & 1 & 6 & 8 & -3.29 & 0.01 & $\begin{array}{l}\text { NADH dehydrogenase } \\
\text { subunit } 7\end{array}$ & Cycas taitungensis & YP_001661405.1 \\
\hline comp36636_c1_seq1 & 30 & 12 & 2 & 3 & 2 & -3.28 & 0.01 & $\begin{array}{l}\text { Transmembrane protein } \\
184 \mathrm{~A}\end{array}$ & Glycine soja & KHN08579.1 \\
\hline comp49034_c0_seq1 & 249 & 183 & 14 & 62 & 22 & -3.27 & 0 & Lipoxygenase & Malus domestica & AGI16408.1 \\
\hline comp28007_c0_seq1 & 70 & 38 & 2 & 6 & 13 & -3.26 & 0 & $\begin{array}{l}\text { Nodulation-signaling } \\
\text { pathway } 1 \text { protein }\end{array}$ & Malus domestica & NP_001287803.1 \\
\hline comp45321_c0_seq2 & 16 & 15 & 0 & 5 & 1 & -3.25 & 0 & Anthocyanidin reductase & Ginkgo biloba & AAU95082.1 \\
\hline comp51062_c0_seq1 & 9 & 23 & 2 & 5 & 0 & -3.23 & 0.03 & $\begin{array}{l}\text { Blue copper protein } \\
\text { precursor }\end{array}$ & Zea mays & NP_001149787.1 \\
\hline comp51256_c0_seq1 & 54 & 21 & 4 & 4 & 5 & -3.23 & 0 & MYBPA1 protein & Vitis vinifera & NP_001268160.1 \\
\hline comp51857_c0_seq1 & 21 & 8 & 2 & 2 & 1 & -3.22 & 0.01 & $\begin{array}{l}\text { E3 ubiquitin-protein ligase } \\
\text { RHA1B }\end{array}$ & Morus notabilis & XP_010112947.1 \\
\hline comp47291_c0_seq1 & 83 & 27 & 8 & 9 & 0 & -3.2 & 0.01 & $\begin{array}{l}\text { ATP-binding cassette } \\
\text { transporter }\end{array}$ & $\begin{array}{l}\text { Selaginella } \\
\text { moellendorffii }\end{array}$ & XP_002991414.1 \\
\hline comp40886_c0_seq1 & 20 & 20 & 0 & 8 & 1 & -3.2 & 0 & Beta-glucosidase & $\begin{array}{l}\text { Medicago } \\
\text { truncatula }\end{array}$ & XP_003636137.1 \\
\hline comp37546_c0_seq1 & 709 & 1526 & 208 & 270 & 40 & -3.16 & 0.04 & Nicotianamine synthase & Lotus japonicus & ВАН22562.1 \\
\hline comp42663_c0_seq1 & 12 & 10 & 2 & 0 & 2 & -3.11 & 0.03 & $\begin{array}{l}\text { Histone-lysine } \\
\mathrm{N} \text {-methyltransferase } \\
\text { ASHH1 }\end{array}$ & Glycine soja & KHN46399.1 \\
\hline comp35349_c0_seq1 & 56 & 18 & 3 & 4 & 7 & -3.11 & 0 & $\begin{array}{l}\text { Zeatin } \\
\text { O-glucosyltransferase }\end{array}$ & Glycine soja & KHN07349.1 \\
\hline comp46467_c0_seq1 & 6 & 27 & 0 & 6 & 4 & -3.1 & 0.05 & Protein HOTHEAD & $\begin{array}{l}\text { Gossypium } \\
\text { arboreum }\end{array}$ & KHG26488.1 \\
\hline comp39845_c0_seq1 & 22 & 41 & 6 & 2 & 5 & -3.08 & 0.02 & Class VII chitinase & Pinus contorta & AEF59007.1 \\
\hline comp53013_c0_seq1 & 10 & 10 & 0 & 0 & 4 & -3.06 & 0.04 & $\begin{array}{l}\text { Sterile alpha motif domain- } \\
\text { containing protein }\end{array}$ & Theobroma cacao & XP_007023327.1 \\
\hline comp51961_c0_seq2 & 16 & 22 & 4 & 2 & 2 & -2.99 & 0.02 & $\begin{array}{l}\text { Histone-lysine } \\
\text { N-methyltransferase } \\
\text { SETD1A }\end{array}$ & Theobroma cacao & XP_007048538.1 \\
\hline comp46618_c0_seq2 & 123 & 148 & 7 & 74 & 6 & -2.98 & 0.02 & Thiazole synthase & $\begin{array}{l}\text { Gossypium } \\
\text { arboreum }\end{array}$ & KHG00545.1 \\
\hline comp26013_c0_seq1 & 13 & 6 & 1 & 2 & 1 & -2.92 & 0.03 & $\begin{array}{l}\text { R2R3-MYB transcription } \\
\text { factor MYB9 }\end{array}$ & Picea glauca & ABQ51225.1 \\
\hline comp49020_c0_seq2 & 239 & 183 & 23 & 99 & 12 & -2.91 & 0.02 & Chitinase 2 & Glycine soja & KHN30221.1 \\
\hline comp44677_c0_seq1 & 75 & 22 & 3 & 11 & 10 & -2.89 & 0.02 & $\begin{array}{l}\text { Adenine nucleotide alpha } \\
\text { hydrolases-like superfamily } \\
\text { protein }\end{array}$ & Theobroma cacao & XP_007044293.1 \\
\hline comp16765_c0_seq1 & 15 & 4 & 1 & 2 & 1 & -2.89 & 0.05 & TPX2 protein family & Theobroma cacao & XP_007032694.1 \\
\hline comp41158_c0_seq1 & 16 & 24 & 3 & 2 & 5 & -2.87 & 0.02 & Uninformative & & \\
\hline comp53914_c0_seq1 & 18 & 34 & 0 & 14 & 4 & -2.87 & 0.02 & LOB domain protein & $\begin{array}{l}\text { Medicago } \\
\text { truncatula }\end{array}$ & XP_003597159.1 \\
\hline
\end{tabular}


Appendix 1. continued

\begin{tabular}{|c|c|c|c|c|c|c|c|c|c|c|}
\hline Reference sequence & $\mathrm{Sm} 3$ & Sm 4 & Sm5 & Sm6 & Sm7 & $\log \mathrm{FC}$ & $\begin{array}{c}\text { PValue } \\
\text { fdr }\end{array}$ & Gene annotation & Organism & Accession No. \\
\hline comp53386_c0_seq1 & 19 & 23 & 4 & 0 & 6 & -2.79 & 0.05 & $\begin{array}{l}\text { Caffeic acid ortho- } \\
\text { methyltransferase }\end{array}$ & Pinus radiata & AAD24001.1 \\
\hline comp242031_c0_seq1 & 12 & 4 & 0 & 4 & 0 & -2.78 & 0.03 & Retrotransposon protein & $\begin{array}{l}\text { Oryza sativa } \\
\text { Japonica Group }\end{array}$ & ABA99600.2 \\
\hline comp49900_c0_seq1 & 10 & 10 & 0 & 2 & 3 & -2.78 & 0.05 & $\begin{array}{l}\text { Nucleolar protein gar2- } \\
\text { related isoform } 2\end{array}$ & Theobroma cacao & XP_007028895.1 \\
\hline comp52440_c0_seq1 & 58 & 23 & 5 & 5 & 10 & -2.77 & 0.01 & Cytochrome P450 & $\begin{array}{l}\text { Gossypium } \\
\text { arboreum }\end{array}$ & KHG08008.1 \\
\hline comp54305_c0_seq10 & 25 & 11 & 2 & 3 & 4 & -2.75 & 0.02 & $\begin{array}{l}\text { Putative potassium } \\
\text { transporter/channel }\end{array}$ & $\begin{array}{l}\text { Arabidopsis } \\
\text { thaliana }\end{array}$ & BAC42897 \\
\hline comp54748_c0_seq12 & 14 & 18 & 3 & 6 & 1 & -2.66 & 0.04 & $\begin{array}{l}\text { RING/U-box superfamily } \\
\text { protein }\end{array}$ & Theobroma cacao & XP_007018124.1 \\
\hline comp45543_c0_seq2 & 59 & 17 & 6 & 10 & 4 & -2.62 & 0.01 & $\begin{array}{l}\text { Lanatoside } \\
15^{\prime} \text {-O-acetylesterase }\end{array}$ & Digitalis lanata & AAY 42522.1 \\
\hline comp38572_c0_seq1 & 134 & 66 & 11 & 42 & 11 & -2.6 & 0.02 & $\begin{array}{l}\text { Clavaminate synthase-like } \\
\text { protein }\end{array}$ & $\begin{array}{l}\text { Arabidopsis } \\
\text { thaliana }\end{array}$ & NP_188773.1 \\
\hline comp55534_c0_seq33 & 170 & 99 & 16 & 63 & 14 & -2.59 & 0.03 & GCR2-like 1 & Theobroma cacao & XP_007047870.1 \\
\hline comp51584_c0_seq1 & 129 & 91 & 6 & 55 & 20 & -2.58 & 0.04 & $\begin{array}{l}\text { ABC-2 and Plant PDR } \\
\text { ABC-type transporter } \\
\text { family protein isoform } 1\end{array}$ & Theobroma cacao & XP_007024294.1 \\
\hline comp52761_c0_seq1 & 39 & 40 & 10 & 13 & 3 & -2.52 & 0.04 & PDR1 & Picea abies & ADP55080.1 \\
\hline comp55358_c0_seq23 & 19 & 26 & 2 & 9 & 5 & -2.5 & 0.02 & Glutamate decarboxylase & Pinus pinaster & ABA18653.1 \\
\hline comp54745_c1_seq1 & 34 & 22 & 4 & 5 & 9 & -2.47 & 0.02 & $\begin{array}{l}\text { PPPDE peptidase domain- } \\
\text { containing } 2\end{array}$ & $\begin{array}{l}\text { Gossypium } \\
\text { arboreum }\end{array}$ & KHG00551.1 \\
\hline comp38121_c0_seq1 & 20 & 11 & 0 & 7 & 4 & -2.46 & 0.03 & $\begin{array}{l}\text { AT-hook motif nuclear } \\
\text { localized protein } 20\end{array}$ & Theobroma cacao & XP_007035040.1 \\
\hline comp46420_c0_seq1 & 36 & 28 & 2 & 14 & 9 & -2.44 & 0.01 & $\begin{array}{l}\text { Pleckstrin homology } \\
\text { domain-containing family } \\
\text { M member } 3\end{array}$ & Morus notabilis & XP_010087674.1 \\
\hline comp51011_c0_seq2 & 20 & 9 & 2 & 6 & 2 & -2.4 & 0.03 & Uninformative & & \\
\hline comp49687_c0_seq1 & 59 & 33 & 8 & 8 & 16 & -2.26 & 0.04 & Uninformative & & \\
\hline comp52634_c0_seq1 & 49 & 28 & 6 & 26 & 5 & -2.25 & 0.03 & $\begin{array}{l}\text { 3-dehydroquinate } \\
\text { dehydratase/shikimate } \\
\text { 5-dehydrogenase }\end{array}$ & Juglans regia & 5140.1 \\
\hline comp43649_c0_seq1 & 56 & 26 & 10 & 8 & 10 & -2.25 & 0.05 & $\begin{array}{l}\text { IAA-leucine resistant-like } \\
\text { gene } 6 \text { isoform } 1\end{array}$ & Theobroma cacao & XP_007019095.1 \\
\hline comp31662_c0_seq1 & 43 & 41 & 7 & 17 & 12 & -2.21 & 0.03 & $\begin{array}{l}\text { Ribulose-5-phosphate-3- } \\
\text { epimerase }\end{array}$ & Ricinus communis & XP_002509539.1 \\
\hline comp50798_c0_seq1 & 48 & 46 & 11 & 20 & 12 & -2.13 & 0.04 & $\begin{array}{l}\text { Putative serine/threonine- } \\
\text { protein kinase WNK11 }\end{array}$ & Glycine soja & KHN43812.1 \\
\hline comp47976_c0_seq1 & 62 & 33 & 6 & 21 & 16 & -2.08 & 0.04 & $\begin{array}{l}\text { Protein ETHYLENE } \\
\text { INSENSITIVE } 3\end{array}$ & Morus notabilis & XP_010106128.1 \\
\hline comp54938_c0_seq1 & 7 & 2 & 14 & 75 & 29 & 2.65 & 0.03 & Cobalamin binding protein & $\begin{array}{l}\text { Desulfosporosinus } \\
\text { meridiei }\end{array}$ & WP_014903849.1 \\
\hline comp19487_c0_seq1 & 10 & 2 & 28 & 88 & 48 & 2.86 & 0.01 & Zinc-binding protein & $\begin{array}{l}\text { Cryptomeria } \\
\text { japonica }\end{array}$ & BAE92295.1 \\
\hline comp54809_c0_seq5 & 7 & 2 & 19 & 118 & 38 & 3.15 & 0.04 & Alpha-mannosidase & $\begin{array}{l}\text { Pyrus } x \\
\text { bretschneideri }\end{array}$ & AGR44468.1 \\
\hline comp50587_c0_seq1 & 4 & 0 & 7 & 80 & 9 & 3.44 & 0.05 & 30 S ribosomal protein $\mathrm{S} 1$ & Glycine soja & KHN23663.1 \\
\hline comp45265_c0_seq2 & 0 & 2 & 9 & 27 & 13 & 3.47 & 0.04 & F-box/kelch-repeat protein & Morus notabilis & XP_010090191.1 \\
\hline comp62062_c0_seq1 & 4 & 0 & 15 & 74 & 12 & 3.52 & 0.02 & $\begin{array}{l}\text { Rhodanese/Cell cycle } \\
\text { control phosphatase } \\
\text { superfamily protein }\end{array}$ & Theobroma cacao & XP_007037783.1 \\
\hline comp556453_c0_seq1 & 3 & 0 & 16 & 42 & 17 & 3.61 & 0.02 & $\begin{array}{l}\text { Pleiotropic drug resistance } \\
11\end{array}$ & Theobroma cacao & XP_007023609.1 \\
\hline
\end{tabular}


Appendix 1. continued

\begin{tabular}{|c|c|c|c|c|c|c|c|c|c|c|}
\hline Reference sequence & Sm3 & Sm4 & Sm5 & Sm6 & $\operatorname{Sm} 7$ & $\log \mathrm{FC}$ & $\begin{array}{c}\text { PValue } \\
\text { fdr }\end{array}$ & Gene & Organism & Accession No. \\
\hline comp32378_c0_seq1 & 2 & 2 & 10 & 85 & 19 & 3.64 & 0.01 & $\begin{array}{l}\text { ATP-dependent Clp } \\
\text { protease proteolytic } \\
\text { subunit }\end{array}$ & Pinus thunbergii & NP_042379.1 \\
\hline comp54841_c0_seq18 & 2 & 1 & 9 & 77 & 10 & 3.64 & 0.04 & NBS/LRR & Pinus taeda & AAM28912.1 \\
\hline comp47096_c0_seq1 & 2 & 0 & 13 & 43 & 6 & 3.71 & 0.03 & $\begin{array}{l}\text { Pentatricopeptide repeat- } \\
\text { containing protein }\end{array}$ & Ricinus communis & XP_002511505.1 \\
\hline comp42175_c0_seq1 & 0 & 3 & 13 & 76 & 19 & 3.81 & 0.03 & Cytochrome P450 78A3 & Morus notabilis & XP_010100198.1 \\
\hline comp52935_c0_seq2 & 2 & 0 & 12 & 40 & 12 & 3.81 & 0.02 & Nitrate transporter & Cucumis sativus & AFR11354.1 \\
\hline comp70039_c0_seq1 & 2 & 2 & 4 & 134 & 8 & 3.83 & 0.05 & $\begin{array}{l}\text { Regulator of G-protein } \\
\text { signaling }\end{array}$ & Chara braunii & AHB52760.1 \\
\hline comp55154_c0_seq1 & 2 & 0 & 10 & 58 & 5 & 3.87 & 0.03 & $\begin{array}{l}\text { Myosin heavy chain- } \\
\text { related }\end{array}$ & Theobroma cacao & XP_007041107.1 \\
\hline comp52063_c0_seq8 & 2 & 0 & 11 & 44 & 14 & 3.89 & 0.02 & Phosphate transporter 1,4 & Theobroma cacao & XP_007050310.1 \\
\hline comp43157_c0_seq1 & 2 & 0 & 13 & 64 & 7 & 3.9 & 0.05 & Clavata-like receptor & Picea glauca & ABF73316.1 \\
\hline comp49546_c1_seq1 & 2 & 0 & 8 & 64 & 6 & 3.92 & 0.04 & $\begin{array}{l}\text { Putative AT-hook DNA- } \\
\text { binding protein }\end{array}$ & $\begin{array}{l}\text { Oryza sativa } \\
\text { Japonica Group }\end{array}$ & BAD10063.1 \\
\hline comp55194_c0_seq1 & 3 & 2 & 13 & 145 & 40 & 3.93 & 0.01 & Too large & & \\
\hline comp49025_c0_seq3 & 1 & 0 & 8 & 18 & 9 & 3.93 & 0.02 & $\begin{array}{l}\text { Heme oxygenase-like, } \\
\text { multi-helical isoform } 1\end{array}$ & Theobroma cacao & XP_007030327.1 \\
\hline comp48011_c0_seq1 & 4 & 0 & 17 & 96 & 17 & 3.94 & 0 & $\begin{array}{l}\text { WRKY transcription factor } \\
14-1\end{array}$ & $\begin{array}{l}\text { Dimocarpus } \\
\text { longan }\end{array}$ & AEO31477.1 \\
\hline comp42365_c0_seq1 & 3 & 0 & 12 & 83 & 22 & 3.96 & 0.01 & Properoxidase & Picea abies & CAL25300.1 \\
\hline comp41730_c0_seq1 & 3 & 0 & 13 & 81 & 18 & 3.99 & 0.01 & $\begin{array}{l}\text { Adenylate kinase } \\
\text { isoenzyme }\end{array}$ & $\begin{array}{l}\text { Medicago } \\
\text { truncatula }\end{array}$ & XP_003617100.1 \\
\hline comp55326_c0_seq4 & 1 & 0 & 5 & 25 & 14 & 4 & 0.03 & $\begin{array}{l}\text { F-box/LRR-repeat } 3 \text {-like } \\
\text { protein }\end{array}$ & $\begin{array}{l}\text { Gossypium } \\
\text { arboreum }\end{array}$ & KHG22457.1 \\
\hline comp35564_c0_seq1 & 2 & 0 & 4 & 82 & 12 & 4.01 & 0.05 & $\begin{array}{l}\text { Pre-mRNA cleavage } \\
\text { complex II protein family } \\
\text { isoform } 1\end{array}$ & Theobroma cacao & XP_007010520.1 \\
\hline comp53805_c0_seq1 & 1 & 0 & 6 & 31 & 10 & 4.09 & 0.02 & $\begin{array}{l}\text { Biotin/lipoate } \mathrm{A} / \mathrm{B} \text { protein } \\
\text { ligase family protein }\end{array}$ & $\begin{array}{l}\text { Arabidopsis } \\
\text { thaliana }\end{array}$ & NP_189543.2 \\
\hline comp55489_c0_seq4 & 1 & 0 & 11 & 21 & 9 & 4.09 & 0.02 & $\begin{array}{l}\text { Pentatricopeptide repeat } \\
\text { (PPR) superfamily protein }\end{array}$ & Theobroma cacao & XP_007043514.1 \\
\hline comp55660_c0_seq1 & 2 & 0 & 6 & 80 & 7 & 4.1 & 0.04 & $\begin{array}{l}\text { SWIM zinc finger family } \\
\text { protein }\end{array}$ & Theobroma cacao & XP_007040728.1 \\
\hline comp51780_c0_seq2 & 1 & 0 & 5 & 33 & 14 & 4.18 & 0.02 & Boron transporter & Ricinus communis & XP_002519293.1 \\
\hline comp48504_c0_seq1 & 0 & 2 & 9 & 93 & 8 & 4.21 & 0.04 & Subtilisin-like protease & Glycine soja & KHN12975.1 \\
\hline comp50903_c0_seq3 & 1 & 0 & 5 & 46 & 8 & 4.24 & 0.02 & $\begin{array}{l}\text { Splicing factor, arginine/ } \\
\text { serine-rich } 12\end{array}$ & Zea mays & ACG33547.1 \\
\hline comp51704_c0_seq1 & 2 & 0 & 6 & 84 & 13 & 4.32 & 0.01 & $\begin{array}{l}\text { NAC domain-containing } \\
\text { protein }\end{array}$ & Glycine soja & KHN03216.1 \\
\hline comp55152_c0_seq2 & 1 & 0 & 12 & 34 & 13 & 4.51 & 0.01 & Isoamylase 2 & Morus notabilis & XP_010090367.1 \\
\hline comp47615_c0_seq1 & 1 & 0 & 3 & 56 & 15 & 4.59 & 0.03 & Cornifelin & $\begin{array}{l}\text { Medicago } \\
\text { truncatula }\end{array}$ & XP_003629262.1 \\
\hline comp43387_c0_seq3 & 1 & 0 & 2 & 66 & 10 & 4.61 & 0.04 & Fibrillin 8 & Coffea canephora & ABD39695.1 \\
\hline comp55616_c0_seq1 & 1 & 0 & 10 & 45 & 17 & 4.68 & 0.01 & $\begin{array}{l}\text { LRR receptor-like serine/ } \\
\text { threonine-protein kinase }\end{array}$ & Theobroma cacao & XP_007029832.1 \\
\hline comp43106_c0_seq1 & 0 & 2 & 46 & 33 & 27 & 4.72 & 0.01 & $\begin{array}{l}\text { Leucine-rich repeat family } \\
\text { protein }\end{array}$ & $\begin{array}{l}\text { Populus } \\
\text { trichocarpa }\end{array}$ & XP_002314568.2 \\
\hline comp42365_c0_seq2 & 3 & 2 & 42 & 271 & 33 & 4.76 & 0.01 & Properoxidase & Picea abies & CAL25300.1 \\
\hline comp18457_c0_seq1 & 1 & 0 & 6 & 86 & 3 & 4.89 & 0.02 & Uninformative & & \\
\hline comp55645_c0_seq1 & 2 & 0 & 19 & 113 & 22 & 4.89 & 0 & $\begin{array}{l}\text { Alpha } 1,3 \\
\text { fucosyltransferase }\end{array}$ & $\begin{array}{l}\text { Populus tremula } \times \\
\text { Populus alba }\end{array}$ & CAI70373.1 \\
\hline comp30617_c0_seq1 & 0 & 2 & 7 & 156 & 40 & 5.02 & 0.02 & $\begin{array}{l}\text { PLATZ transcription factor } \\
\text { family protein isoform } 2\end{array}$ & Theobroma cacao & XP_007018634.1 \\
\hline
\end{tabular}


Appendix 1. continued

\begin{tabular}{|c|c|c|c|c|c|c|c|c|c|c|}
\hline Reference sequence & Sm3 & $\operatorname{Sm} 4$ & Sm5 & Sm6 & Sm7 & $\log \mathrm{FC}$ & $\begin{array}{c}\text { PValue } \\
\text { fdr }\end{array}$ & Gene annotation & Organism & Accession No. \\
\hline comp53594_c0_seq1 & 1 & 0 & 4 & 96 & 9 & 5.05 & 0.02 & $\begin{array}{l}\text { Nucleotide-diphospho- } \\
\text { sugar transferases } \\
\text { superfamily protein }\end{array}$ & Theobroma cacao & XP_007029705.1 \\
\hline comp54467_c0_seq3 & 1 & 0 & 7 & 118 & 9 & 5.23 & 0.02 & $\begin{array}{l}\text { Exosome complex } \\
\text { exonuclease RRP46 like }\end{array}$ & Glycine soja & KHM99392.1 \\
\hline comp20002_c0_seq1 & 0 & 0 & 5 & 22 & 6 & 5.3 & 0.05 & Protein lifeguard 4 & $\begin{array}{l}\text { Arabidopsis } \\
\text { thaliana }\end{array}$ & NP_171806.1 \\
\hline comp52704_c0_seq1 & 0 & 0 & 7 & 18 & 7 & 5.36 & 0.04 & $\begin{array}{l}\text { Pentatricopeptide repeat- } \\
\text { containing protein }\end{array}$ & Ricinus communis & XP_002532091.1 \\
\hline comp51350_c0_seq1 & 0 & 0 & 6 & 19 & 10 & 5.46 & 0.04 & Subtilisin-like protein & Picea abies & BAA13135.1 \\
\hline comp55244_c0_seq5 & 0 & 0 & 4 & 27 & 8 & 5.5 & 0.04 & $\begin{array}{l}\text { LRR receptor-like serine/ } \\
\text { threonine-protein kinase } \\
\text { FLS2 }\end{array}$ & Triticum urartu & EMS54167.1 \\
\hline comp50151_c0_seq1 & 0 & 0 & 6 & 26 & 7 & 5.51 & 0.03 & Protein FAM91A1 & $\begin{array}{l}\text { Gossypium } \\
\text { arboreum }\end{array}$ & KHG03579.1 \\
\hline comp53367_c0_seq2 & 0 & 0 & 11 & 19 & 4 & 5.56 & 0.05 & $\begin{array}{l}\text { TPA: putative WAK } \\
\text { receptor-like protein kinase } \\
\text { family protein }\end{array}$ & Zea mays & DAA38848.1 \\
\hline comp18781_c0_seq1 & 0 & 0 & 12 & 20 & 6 & 5.66 & 0.02 & F-box family protein & $\begin{array}{l}\text { Populus } \\
\text { trichocarpa }\end{array}$ & XP_002315636.1 \\
\hline comp41403_c0_seq1 & 0 & 0 & 8 & 37 & 4 & 5.77 & 0.03 & $\begin{array}{l}\text { Condensin-2 complex } \\
\text { subunit D3 isoform } 3\end{array}$ & Theobroma cacao & XP_007035610.1 \\
\hline comp50394_c0_seq2 & 0 & 0 & 10 & 24 & 9 & 5.79 & 0.02 & $\begin{array}{l}\text { Circadian clock coupling } \\
\text { factor family protein }\end{array}$ & $\begin{array}{l}\text { Populus } \\
\text { trichocarpa }\end{array}$ & XP_002306041.1 \\
\hline comp38917_c0_seq1 & 0 & 0 & 6 & 30 & 11 & 5.81 & 0.02 & Coatomer subunit beta & $\begin{array}{l}\text { Medicago } \\
\text { truncatula }\end{array}$ & КEH28616.1 \\
\hline comp42062_c0_seq1 & 0 & 0 & 6 & 37 & 7 & 5.84 & 0.03 & $\begin{array}{l}\text { Serine-threonine protein } \\
\text { kinase, plant-type }\end{array}$ & Ricinus communis & XP_002526889.1 \\
\hline comp55102_c0_seq1 & 0 & 0 & 12 & 31 & 2 & 5.85 & 0.03 & $\begin{array}{l}\text { Putative TIR-NBS-LRR } \\
\text { protein }\end{array}$ & Pinus monticola & ADW94527.1 \\
\hline comp48926_c0_seq1 & 0 & 0 & 8 & 35 & 7 & 5.9 & 0.02 & Zinc finger protein 4 & Theobroma cacao & XP_007032204.1 \\
\hline comp42562_c0_seq1 & 0 & 0 & 13 & 18 & 16 & 5.9 & 0.05 & $\begin{array}{l}\text { Plant-specific domain } \\
\text { TIGR01615 family protein }\end{array}$ & Zea mays & NP_001147221.1 \\
\hline comp49784_c0_seq1 & 0 & 0 & 13 & 32 & 3 & 5.94 & 0.02 & Uninformative & & \\
\hline comp20321_c0_seq2 & 0 & 0 & 9 & 46 & 2 & 6 & 0.03 & $\begin{array}{l}\text { BRCA1-A complex subunit } \\
\text { Abraxas }\end{array}$ & $\begin{array}{l}\text { Gossypium } \\
\text { arboreum }\end{array}$ & KHG22147.1 \\
\hline comp50442_c0_seq1 & 0 & 0 & 10 & 34 & 4 & 6 & 0.01 & $\begin{array}{l}\text { U-box domain-containing } \\
\text { protein } 4\end{array}$ & Morus notabilis & XP_010110625.1 \\
\hline comp41706_c0_seq1 & 0 & 0 & 5 & 59 & 2 & 6.06 & 0.05 & $\begin{array}{l}\text { Plastid RNA polymerase } \\
\text { sigma factor X }\end{array}$ & $\begin{array}{l}\text { Marchantia } \\
\text { polymorpha }\end{array}$ & BAM95333.1 \\
\hline comp470497_c0_seq1 & 0 & 1 & 9 & 217 & 18 & 6.1 & 0 & Patatin-T5 & Aegilops tauschii & EMT08201.1 \\
\hline comp54342_c0_seq1 & 0 & 0 & 9 & 47 & 6 & 6.11 & 0.01 & $\begin{array}{l}\text { long cell-linked locus } \\
\text { protein }\end{array}$ & Zea mays & NP_001147138.1 \\
\hline comp53191_c0_seq1 & 0 & 0 & 6 & 50 & 8 & 6.15 & 0.02 & $\begin{array}{l}\text { Putative leucine-rich repeat } \\
\text { receptor-like protein kinase } \\
\text { family protein }\end{array}$ & Zea mays & AFW83643.1 \\
\hline comp41173_c0_seq1 & 0 & 0 & 2 & 52 & 17 & 6.19 & 0.04 & Subtilase family protein & Theobroma cacao & XP_007024651.1 \\
\hline comp55364_c0_seq1 & 0 & 0 & 2 & 71 & 6 & 6.22 & 0.05 & Proline--tRNA ligase & $\begin{array}{l}\text { Gossypium } \\
\text { arboreum }\end{array}$ & KHG24304.1 \\
\hline comp52104_c0_seq1 & 0 & 0 & 5 & 70 & 7 & 6.39 & 0.02 & $\begin{array}{l}\text { Aspartic proteinase Asp1 } \\
\text { precursor }\end{array}$ & Ricinus communis & XP_002514831.1 \\
\hline comp35394_c0_seq1 & 0 & 0 & 8 & 74 & 4 & 6.48 & 0.02 & DIS3-like exonuclease 1 & Bos taurus & NP_001071624.1 \\
\hline comp51856_c0_seq1 & 0 & 0 & 1 & 72 & 16 & 6.53 & 0.02 & Transmembrane protein $8 \mathrm{~B}$ & Glycine soja & KHN26950.1 \\
\hline comp54808_c0_seq4 & 0 & 0 & 5 & 83 & 11 & 6.58 & 0.01 & $\begin{array}{l}\text { Putative TIR-NBS-LRR } \\
\text { protein }\end{array}$ & Pinus monticola & ADW94527.1 \\
\hline
\end{tabular}


Appendix 1. continued

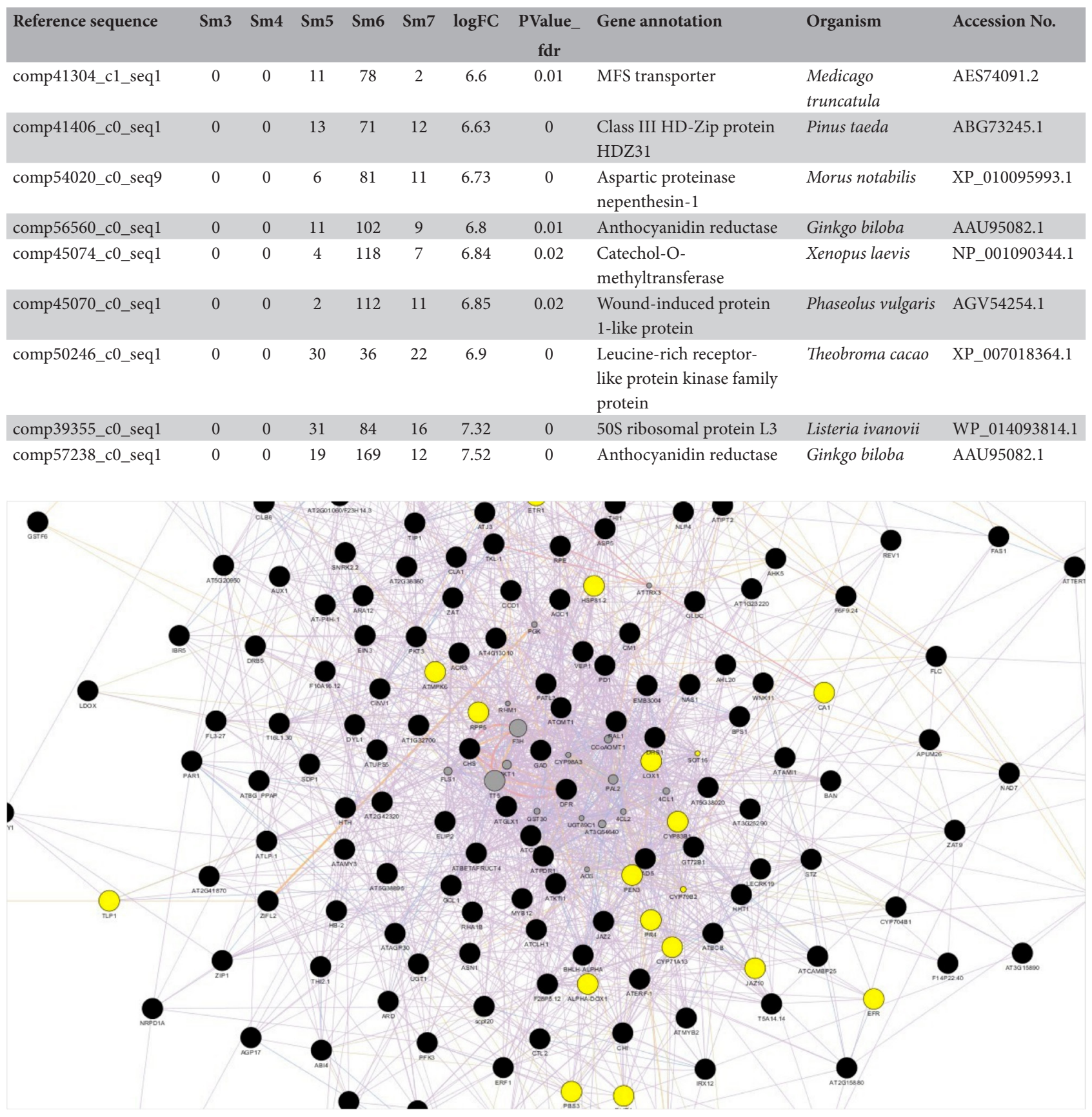

Appendix 2. The center of the up regulated gene network. Black nodes are genes from imported list, grey nodes are genes added by the Cytoscape 3.2.1 program. Genes highlighted in yellow are involved in immune responses. 


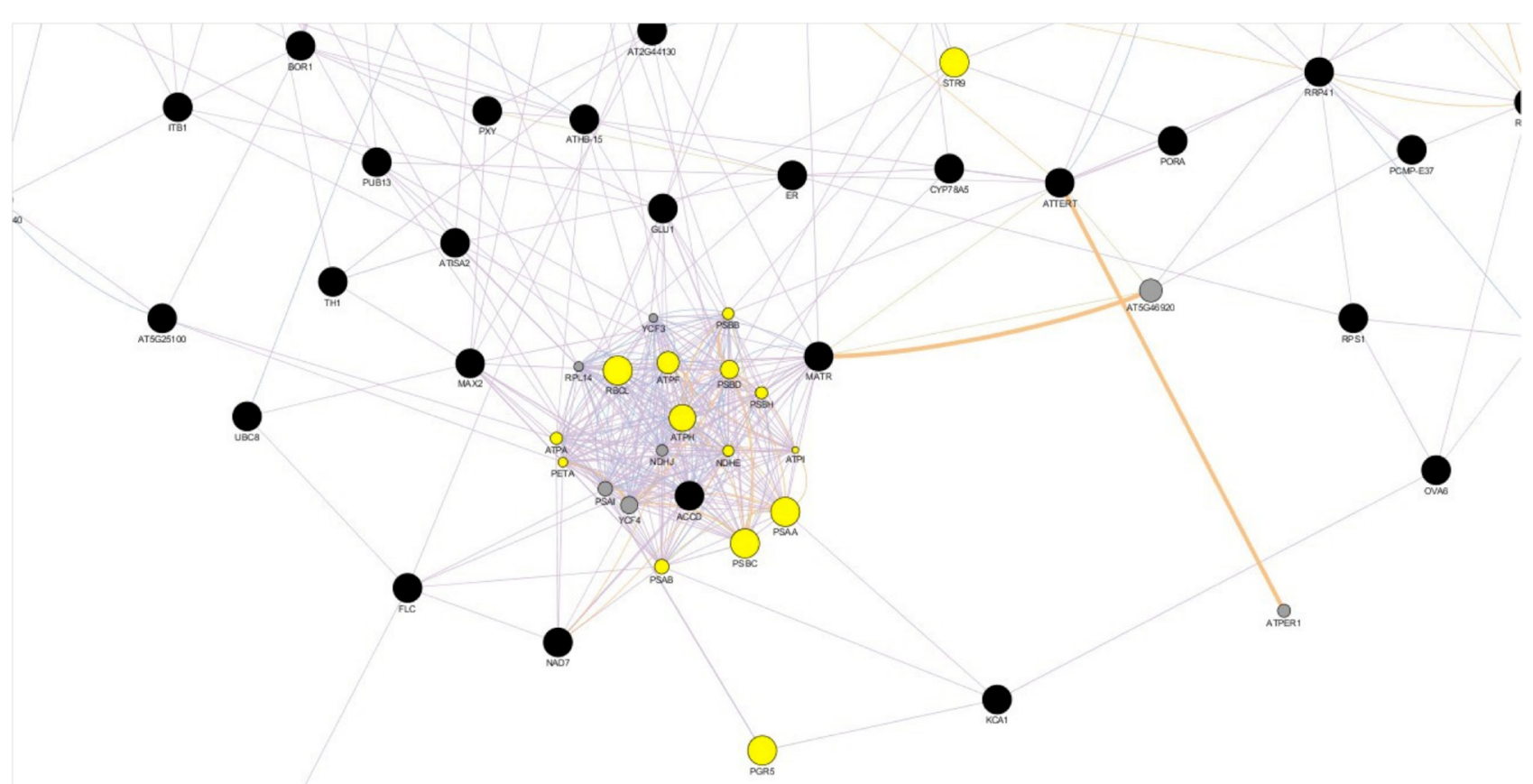

Appendix 3. The center of the down regulated gene network. Black nodes are genes from imported list, grey nodes are genes added by the Cytoscape 3.2.1 program. Genes highlighted in yellow are coding proteins associated with the chloroplast thylakoid membrane. 